\title{
The bubble snails (Gastropoda, Heterobranchia) of Mozambique: an overlooked biodiversity hotspot
}

\author{
Yara Tibiriçá $^{1,2}$ • Manuel António E. Malaquias ${ }^{3}$
}

Received: 9 October 2015 /Revised: 14 March 2016/Accepted: 17 April 2016/Published online: 20 May 2016

(C) The Author(s) 2016. This article is published with open access at Springerlink.com

\begin{abstract}
This first account, dedicated to the shallow water marine heterobranch gastropods of Mozambique is presented with a focus on the clades Acteonoidea and Cephalaspidea. Specimens were obtained as a result of sporadic sampling and two dedicated field campaigns between the years of 2012 and 2015 , conducted along the northern and southern coasts of Mozambique. Specimens were collected by hand in the intertidal and subtidal reefs by snorkelling or SCUBA diving down to a depth of $33 \mathrm{~m}$. Thirty-two species were found, of which 22 are new records to Mozambique and five are new for the Western Indian Ocean. This account raises the total number of shallow water Acteonoidea and Cephalaspidea known in Mozambique to 39 species, which represents approximately $50 \%$ of the Indian Ocean diversity and $83 \%$ of the diversity of these molluses found in the Red Sea. A gap in sampling was identified in the central swamp/mangrove bio-region of Mozambique, and therefore, we suggest that future research efforts concentrate on or at least consider this region.
\end{abstract}

Communicated by V. Urgorri

Manuel António E. Malaquias

Manuel.Malaquias@uib.no

1 A.C.C.M. Zavora Marine Lab, Zavora, Inharrime, Inhambane Province 1113, Mozambique

2 Department of Biology, Faculty of Marine and Environmental Sciences, University of Cádiz, Poligono del Rio San Pedro s/n, Apdo. 40, 11510 Puerto Real, Cadiz, Spain

3 Phylogenetic Systematics and Evolution Research Group, Section of Taxonomy and Evolution, Department of Natural History, University Museum of Bergen, University of Bergen, Bergen PB 7800, 5020, Norway
Keywords Mollusca $\cdot$ Acteonoidea $\cdot$ Cephalaspidea $\cdot$ Sea slugs $\cdot$ Taxonomy $\cdot$ Biodiversity $\cdot$ Africa $\cdot$ Western Indian Ocean

\section{Introduction}

The shallow water marine heterobranch gastropods (sea slugs and alikes) of the Western Indian Ocean (WIO), an area confined between the East African coast and the Saya de Malha, Nazareth, and Cargados Carajos banks of the Mascarene Plateau (Obura 2012), have received little attention when compared to other parts of the Indo-West Pacific, and most accounts are relatively old with few recent contributions (e.g. von Martens 1879; Bergh 1900; Eliot 1904, 1905, 1906; Barnard 1927; MacNae and Kalk 1958, 1962; Rudman 1972b; Gosliner 1987; Yonow and Hayward 1991; Branch et al. 2008; Gosliner et al. 2008, 2015; Malaquias and Reid 2008; Price et al. 2011; Yonow 2012; Carmona et al. 2014a; King and Fraser 2014).

Mozambique has the third largest coastline among eastern African countries, stretching over 2,400 km across subtropical and tropical latitudes. Few works have reported the occurrence of marine heterobranch gastropod species in the country and no dedicated account is available. The latter are either generalistic faunistic reports (Bergh 1900; MacNae and Kalk 1958, 1962), field guides covering broader geographical regions (Branch et al. 2008; Gosliner et al. 2008, 2015; King and Fraser 2014), or systematic revisions of certain genera (Malaquias and Reid 2008; Price et al. 2011; Carmona et al. 2014a).

Gosliner et al. (2008), in their book about the shallowwater sea slugs (Heterobranchia in part) of the tropical and adjacent temperate areas of the Indo-West Pacific region (IWP), have cited the occurrence of 1397 species, but of those 
only 16 were specifically reported to occur in Mozambique, representing little more than $1 \%$ of the known diversity of the entire IWP. This low number of species is in sharp contrast to the richness of marine life in IWP countries and the diversity of ecosystems in Mozambique where three major bio-regions are recognized: (1) the subtropical submerged rocky reefs on the south between Ponta do Ouro on the border with South Africa $\left(26^{\circ} 51^{\prime} \mathrm{S}\right)$ and the Bazaruto archipelago $\left(22^{\circ} 05^{\prime} \mathrm{S}\right)$, (2) the central mangrove/swamp region between Bazaruto and Pebane $\left(17^{\circ} 05^{\prime} \mathrm{S}\right)$, and (3) the tropical coral reefs in the north between Pebane and the Rovuma River on the border with Tanzania $\left(10^{\circ} 28^{\prime} \mathrm{S}\right)$ (Ministry for the Coordination of Environmental Affairs 1997; Pereira et al. 2014). Moreover, the Mozambique Channel is an extremely productive area due to a complex upwelling pattern and converging eddy dipoles (Pereira et al. 2014; Ternon et al. 2014). This diversity of biota and high oceanic productivity contributes to an explanation of the recognized high marine biodiversity of the country reported for some taxonomic groups; for example, Mozambique is known to have the second highest diversity of corals in the entire Indo-Pacific (Obura 2012).

The marine heterobranch gastropods contain some of the most spectacular and colourful gastropods of our seas, of which the nudibranchs are a prime example (Gosliner et al. 2008, 2015). The aesthetic value of these animals makes them one of the most appealing groups for recreational divers and has triggered the development of a dedicated industry of safaris and cruises (e.g. Nudibranch cruises in Indonesia [http:// www.thearenui.com/VanessaKnutson2016Komodo.html] and the Nudibranch Safari in Norway at Gulen [http://www. scubapixel.com/blog/20715-nudibranch-safari-2016]).

The systematics of heterobranch gastropods went through dramatic rearrangements in recent years. The traditional clade Opisthobranchia, previously regarded as one of the three subclasses of Gastropoda (Kay et al. 1998; Burn and Thompson 1998), is now considered polyphyletic, and the relationships and composition of several of its previous lineages have suffered striking reorganisations (Jörger et al. 2010; Schrödl 2014; Oskars et al. 2015). The formal use of the name Opisthobranchia has been abandoned in recent works (e. g. Schrödl 2014; Caballer et al. 2015); for example, the order Cephalaspidea (bubble snails), which previously included the acteonids (Acteon, Pupa), ringiculids (Ringicula), aplustrids (Hydatina, Micromelo), runcinids (Runcina), plus all other traditional cephalaspids (e.g. aglajids, bullids, diaphanids, haminoeids, etc.) (see Burn and Thompson 1998), has been split into three independent lineages of equal rank, namely the Acteonoidea (now part of the so called "Lower Heterobranchs"), the Runcinacea, and the Cephalaspidea (Mikkelsen 1996; Vonnemann et al. 2005; Malaquias et al. 2009). The latter two clades are included in a larger group termed Euopisthobranchia (Jörger et al. 2010; Schrödl 2014).
This paper provides the first dedicated account on the marine heterobranchs clades Acteonoidea and Cephalaspidea of Mozambique, based on a review of the literature and newly collected material. These two groups are commonly designated as bubble snails because of the presence of a rounded shell with an involute or short spire in many genera; they occur mostly in shallow coastal areas in soft substrates of mud, sand, and seagrass, but there are exceptions with some genera (e.g. Philine, Scaphander) extending their bathymetric distribution into the deep sea, as well as a single genus that is specialized in intertidal and shallow subtidal rocky-shores (Smaragdinella) (Gosliner et al. 2008; Oskars et al. 2015).

\section{Material and methods}

Specimens were collected as a result of sporadic sampling along the coast of Mozambique (Fig. 1) during 4 years between 2012 and 2015 and during two dedicated field campaigns: 23 Jan-03 Feb 2014 in Inhambane Province, southern Mozambique and 12-28 May 2015 around Pemba and Vamizi Island, northern Mozambique. Specimens were collected by snorkelling and SCUBA diving between the tidal zone and up to a depth of $33 \mathrm{~m}$. Several subtropical and tropical habitats were surveyed including tidal and subtidal reefs, fringing coral reefs, submerged rocky reefs, seagrass, sand flats, and estuaries (Table 1). All specimens were collected by hand, measured (total length "TL"), and photographed. Specimens were frozen in seawater overnight, defrosted, and transferred to $96 \%$ ethanol.

The classification and nomenclature adopted in this work mostly follows the World Register of Marine Species (WoRMS Editorial Board 2015), but for higher ranks we adopted Schrödl (2014). Voucher specimens were deposited at the Department of Natural History of the University Museum of Bergen, Norway (ZMBN), and at the Zavora Marine Laboratory, A.C.C.M., Mozambique (YT). Duplicates of these collections are deposited at the Natural History Museum of Maputo, Mozambique (MHN).

\section{Results}

In total, 32 species were recorded during our surveys; four species of Acteonoidea and 28 species of Cephalaspidea. Eight families were sampled, with Aglajidae being the most diverse with 13 species, followed by Haminoeidae (seven species), Philinidae and Aplustridae (three species each), Bullidae and Gastropteridae (two species each), and Acteonidae and Colpodaspididae (one each).

Twenty-two species are new records to Mozambique and five of them are first cited in the Western Indian Ocean (WIO). 
Fig. 1 Main collecting areas; for details of sampling sites, see Table 1

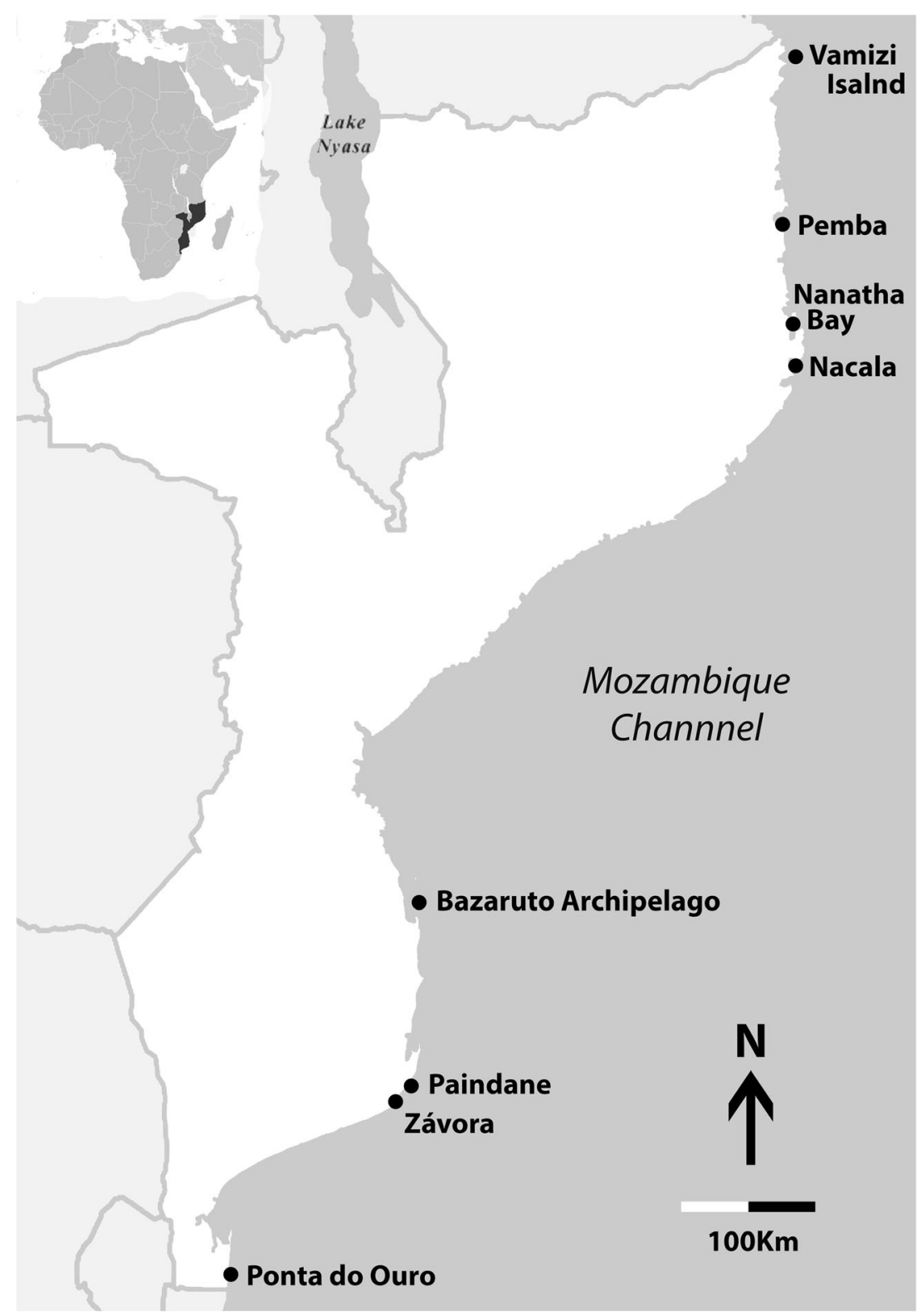

Taxonomic list

Class GASTROPODA Cuvier, 1797

Subclass HETEROBRANCHIA Burmeister, 1837

Clade ACTEONACEA d'Orbigny 1835

Superfamily ACTEONOIDEA d'Orbigny, 1843

Family ACTEONIDAE d'Orbigny, 1843

Genus Pupa Röding, 1798

Pupa suturalis (A. Adams, 1855)

(Fig. 2a)

Material examined: BLE, 1 spc., 25 January 2014, $\mathrm{TL}=8 \mathrm{~mm}$ (shell length), ZMBN 94186.

Ecology: Crawling on sand, $1 \mathrm{~m}$ deep at dusk.
Distribution: Occurs throughout the IWP; Papua New Guinea (Gosliner et al. 2008), Australia (Rudman 1971; Gosliner et al. 2008), and the Philippines (Gosliner et al. 2008). WIO: Tanzania (Adams 1855), Mozambique (present study), and South Africa (Gosliner 1987: 39 as Japonacteon sp.; Gosliner et al. 2008).

Remarks: First record for Mozambique.

Family APLUSTRIDAE Gray, 1847

Genus Aplustrum Schumacher, 1817

Aplustrum amplustre (Linnaeus, 1758)

(Fig. 2b)

Material examined: PTR, 10 spcs, 2 February 2014, $\mathrm{TL}=8-15 \mathrm{~mm}$ (shell length), ZMBN 94213. 
Table 1 Sampling stations with geographical coordinates and biophysical descriptions

\begin{tabular}{|c|c|c|c|}
\hline Sampling station & Code & Coordinates & Description \\
\hline Ponta do Ouro (Blacks) & POB & $26^{\circ} 49^{\prime} 45^{\prime \prime} \mathrm{S}-32^{\circ} 53^{\prime} 51^{\prime \prime} \mathrm{E}$ & $\begin{array}{l}\text { Small subtropical submerged rocky reef with seagrass; average } \\
\text { depth } 15 \mathrm{~m} \text {, maximum } 18 \mathrm{~m}\end{array}$ \\
\hline Ponta do Ouro (Checkers) & POC & $26^{\circ} 49^{\prime} 45^{\prime \prime} \mathrm{S}-32^{\circ} 53^{\prime} 51^{\prime \prime} \mathrm{E}$ & $\begin{array}{l}\text { Subtropical submerged rocky reef; limestone formation with low } \\
\text { coral cover but high abundance of benthic life such as sponges } \\
\text { and ascidians; average depth } 15 \mathrm{~m}\end{array}$ \\
\hline Zavora (Rock Pool) & ZRP & $24^{\circ} 31^{\prime} 19^{\prime \prime} \mathrm{S}-35^{\circ} 12^{\prime} 10^{\prime \prime} \mathrm{E}$ & $\begin{array}{l}\text { Subtropical tidal limestone reef forming a pool with an area of } \\
\text { approximately } 200 \times 100 \mathrm{~m} \text { with high abundance of soft coral } \\
\text { and hard coral; maximum } 3 \mathrm{~m} \text { deep }\end{array}$ \\
\hline Zavora (Doxa Pool) & ZDP & $24^{\circ} 30^{\prime} 28^{\prime \prime} \mathrm{S}-35^{\circ} 12^{\prime} 05^{\prime \prime} \mathrm{E}$ & $\begin{array}{l}\text { Subtropical tidal limestone reef exposed only during low tide and } \\
\text { open to the ocean; few loose large rocks; rocks mainly covered } \\
\text { by algae; average depth } 0.3 \mathrm{~m}\end{array}$ \\
\hline Zavora (Area 51) & ZA51 & $24^{\circ} 27^{\prime} 38^{\prime \prime} \mathrm{S}-35^{\circ} 14^{\prime} 88^{\prime \prime} \mathrm{E}$ & $\begin{array}{l}\text { Subtropical submerged rocky reef with low coral coverage but } \\
\text { high abundance of benthic life such as sponges and ascidians; } \\
\text { average depth } 8 \mathrm{~m}\end{array}$ \\
\hline Paindane Tidal Reef & PTR & $24^{\circ} 06^{\prime} 32^{\prime \prime} \mathrm{S}-35^{\circ} 29^{\prime} 58^{\prime \prime} \mathrm{E}$ & $\begin{array}{l}\text { Subtropical limestone tidal reef with rocks, algae, and patches of } \\
\text { sandy bottom, forming a lagoon during low tide; average depth } \\
0.3 \mathrm{~m}\end{array}$ \\
\hline BazarutoArchipelago, Two Mile Reef & TMR & $21^{\circ} 48^{\prime} 14^{\prime \prime} \mathrm{S}-35^{\circ} 30^{\prime} 20^{\prime \prime} \mathrm{E}$ & $\begin{array}{l}\text { Subtropical/tropical reef between with high abundance of hard } \\
\text { corals as well subtropical species of fish and invertebrates; } \\
\text { average depth } 14 \mathrm{~m}\end{array}$ \\
\hline Barra Lagoon Estuary, Inhambane & BLE & $23^{\circ} 47^{\prime} 15^{\prime \prime} \mathrm{S}-35^{\circ} 29^{\prime} 76^{\prime \prime} \mathrm{E}$ & $\begin{array}{l}\text { Estuary opening to the ocean with sandy bottoms mixed with } \\
\text { seagrass beds; average depth } 4 \mathrm{~m}\end{array}$ \\
\hline Nacala Relanzapu Beach & NRB & $14^{\circ} 28^{\prime} 75^{\prime \prime} \mathrm{S}-40^{\circ} 49^{\prime} 78^{\prime \prime} \mathrm{E}$ & $\begin{array}{l}\text { Long beach with patches of tropical coral reef and rocks at 1-2 m } \\
\text { deep }\end{array}$ \\
\hline Nuarro, Nanatha Bay (Fish Alley) & NEL & $14^{\circ} 11^{\prime} 85^{\prime \prime} \mathrm{S}-40^{\circ} 40^{\prime} 79^{\prime \prime \prime} \mathrm{E}$ & $\begin{array}{l}\text { Fringing tropical coral reef with approximately } 400 \mathrm{~m} \text { width } \\
\text { ending on a drop off down to } 50 \mathrm{~m} \text { depth }\end{array}$ \\
\hline Pemba (aquaculture farm, near harbour) & PAN & $12^{\circ} 59^{\prime} 51^{\prime \prime} \mathrm{S}-40^{\circ} 29^{\prime} 05^{\prime \prime} \mathrm{E}$ & $\begin{array}{l}\text { Aquaculture fish nets covered with algae located on a tropical } \\
\text { embayment; average depth } 4 \mathrm{~m}\end{array}$ \\
\hline Pemba Hotel, pier & PHP & $12^{\circ} 57^{\prime} 95^{\prime \prime} \mathrm{S}-40^{\circ} 32^{\prime} 00^{\prime \prime} \mathrm{E}$ & $\begin{array}{l}\text { Pier located at Pemba Bay close to patches of coral reef and large } \\
\text { stones; } 0.3-2 \mathrm{~m} \text { deep. }\end{array}$ \\
\hline Vamizi Island, north coast (Erwan S3) & VIS3 & $11^{\circ} 00^{\prime} 18^{\prime \prime} \mathrm{S}-40^{\circ} 36^{\prime} 55^{\prime \prime} \mathrm{E}$ & $\begin{array}{l}\text { Shallow tropical fringing reef formed mainly by hard corals } \\
\text { contiguous to fine sandy bottom; average depth } 6 \mathrm{~m}\end{array}$ \\
\hline Vamizi Island, north coast & VIR & $11^{\circ} 00^{\prime} 75^{\prime \prime} \mathrm{S}-40^{\circ} 40^{\prime} 65^{\prime \prime} \mathrm{E}$ & $\begin{array}{l}\text { Shallow tropical fringing reef formed mainly by hard corals } \\
\text { contiguous to fine sandy bottom; average depth } 5 \mathrm{~m}\end{array}$ \\
\hline Vamizi Island, off Lance village & VISG & $11^{\circ} 00^{\prime} 47^{\prime \prime} \mathrm{S}-40^{\circ} 35^{\prime} 35^{\prime \prime} \mathrm{E}$ & $\begin{array}{l}\text { Seagrass banks close to coral reefs with sandy bottoms; average } \\
\text { depth } 4 \mathrm{~m}\end{array}$ \\
\hline Vamizi Island, off Ponta Papagaio & VIPP & $10^{\circ} 59^{\prime} 64^{\prime \prime} \mathrm{S}-40^{\circ} 42^{\prime} 66^{\prime \prime} \mathrm{E}$ & $\begin{array}{l}\text { Shallow coral reef with drop off between } 4 \text { and } 40 \mathrm{~m} \text { with patches } \\
\text { of sandy bottom }\end{array}$ \\
\hline Vamizi Island, Muntu Nkulu & VIM & $11^{\circ} 01^{\prime} 37^{\prime \prime} \mathrm{S}-40^{\circ} 41^{\prime} 42^{\prime \prime} \mathrm{E}$ & $\begin{array}{l}\text { Inlet lined with mangroves and limestone opening to the ocean; } \\
\text { average depth } 0.5 \mathrm{~m} \text {. }\end{array}$ \\
\hline
\end{tabular}

Ecology: Crawling on rocks with algae at night; $0.3 \mathrm{~m}$ deep.

Distribution: Indo-Pacific; Hawaii (Quirk and Wolfe 1974; Moretzsohn and Kay 1995; Gosliner et al. 2008), Marshall Is (Johnson and Boucher 1983 as Hydatina amplustre), Guam (Carlson and Hoff 2003 as Hydatina amplustre), and Fiji (Brodie and Brodie 1990). WIO: Mauritius (Yonow and Hayward 1991), Madagascar, Tanzania (Gosliner et al. 2008), Mozambique (MacNae and Kalk 1958, 1962; Gosliner 1987; present study), and South Africa (Gosliner 1987 as Hydatina amplustre; Gosliner et al. 2008).
Genus Hydatina Schumacher, 1817

\section{Hydatina physis (Linnaeus, 1758)}

(Fig. 2c, d)

Material examined: ZRP, 5 spcs, 07 February 2012, TL = 12-32 mm, YT 159, 161, 171, 172, 185. ZRP, 1 spc., 21 February, 2012, TL=45 mm, YT 265. ZDP, 1 spc., 21 January 2014, TL=35 mm, ZMBN 94157. PTR, 12 spcs, 26 January, 2014, TL $=8-20$ mm, ZMBN 94190. PTR, 3 spcs, 1 February 2014, TL $=12-25 \mathrm{~mm}$ (shell length), ZMBN 94199. ZRP, 5 spcs, 3 February 2014, TL=13-25 mm, ZMBN 94244. VISG, 1 spc., 21 May 2015, TL=40 mm (shell), ZMBN 105154. 
Ecology: Found actively crawling during day and night in shallow and intertidal waters between 0.2 and $4 \mathrm{~m}$ deep. Mating and spawning recorded in May and December. The egg mass has a white flower-shaped structure, measuring approximately $80 \times 30 \mathrm{~mm}$ (see Fig. 2 d). Observed feeding upon marine worms.

Distribution: Circumtropical; Hawaiian Is (Pilsbry 1921; Moretzsohn and Kay 1995; Hoover 1998), Marshall Is (Johnson and Boucher 1983), Guam (Carlson and Hoff 2003), Australia (Burn 2006), and Red Sea (Yonow 2008). WIO: Mauritius (Yonow and Hayward 1991), Mozambique (Gosliner 1987; Branch et al. 2008; Gosliner et al. 2008; King and Fraser 2014), and South Africa (Gosliner 1987; Gosliner et al. 2008). In Mozambique it was previously recorded from Inhaca I. (MacNae and Kalk 1958), Inhambane, and Mozambique Island (von Martens 1879). Also recorded from warm waters on both sides of the Atlantic Ocean (Rolán 2005; Valdés et al. 2006).

Remarks: The systematics of the genus Hydatina is in need of a comprehensive revision using morphological and DNA characters. Specimens similar to the one illustrated here (Fig. 2c) from tropical and sub-tropical regions across the globe have often been named Hydatina physis or Hydatina vesicaria (Voskuil et al. 1995; Wirtz 1999). All specimens observed in Mozambique had the typical color morph observed in the Indo-Pacific, with a bluish colour on the mantle edge instead of the whitish colouration more common in Atlantic Ocean specimens (Wirtz 1999).

Genus Micromelo Pilsbry, 1895

Micromelo undatus (Brugière, 1792)

(Fig. 2e)

Material examined: ZRP, 1 spc., 23 February 2012, $\mathrm{TL}=16 \mathrm{~mm}$, YT518. ZDP, 1 spc., 5 November 2013, $\mathrm{TL}=15 \mathrm{~mm}$, YT 946. ZRP, 2 spcs, 3 February 2014, $\mathrm{TL}=21,25 \mathrm{~mm}, \mathrm{ZMBN} 94236$.

Ecology: Found actively crawling during day and at night on the reef and sand between 0.2 and $3 \mathrm{~m}$ deep.

Distribution: Circumtropical; Hawaiian Is (Kay 1979; Bertsch and Johnson 1981 as Micromelo guamensis), Australia (Wagele et al. 2006), Guam (Carlson and Hoff 2003; Gosliner et al. 2008), Fiji (Brodie and Brodie 1990), and Red Sea (Gosliner et al. 2008). WIO: Mozambique (MacNae and Kalk 1958; Branch et al. 2008; Gosliner et al. 2008; King and Fraser 2014), and South Africa (Gosliner 1987; Gosliner et al. 2008). In the Atlantic Ocean it is known from Ascension I. (Padula et al. 2014), the Cape Verde Is (Rolán 2005), Canary Is (Moro et al. 2003), Azores (Nordsieck 1972), Caribbean (see
Valdés et al. 2006), and Brazil (Padula et al. 2012).

Remarks: The genus Micromelo is also in need of a systematic revision based on both morphological and DNA characters. For example, Micromelo undatus is considered a circumtropical species, but close examination of colour photos of specimens from around the world show several striking chromatic differences that may indicate the existence of several species (Nakano 2004; García et al. 2008; Gosliner et al. 2008, 2015).

Clade TECTIPLEURA Schrödl, Jörger, Klussmann-Kolb \& Wilson, 2011

Superorder EUOPISTHOBRANCHIA Jörger, Stöger, Kano, Fukuda, Knebelsberger \& Schrödl, 2010

Order CEPHALASPIDEA Fischer, 1883

Family AGLAJIDAE Pilsbry, 1895 (1847)

Genus Chelidonura A. Adams, 1850

Chelidonura livida Yonow, 1994

(Fig. 2f)

Material examined: NEL, 2 spcs, 27 December 2014, $\mathrm{TL}=c a .14 \mathrm{~mm}$, photography available only.

Ecology: Observed crawling on sand in shallow waters close to the reef around $10 \mathrm{~m}$ deep.

Distribution: Apparently restricted to the Red Sea (Yonow 1994) and WIO: Madagascar, Tanzania (Gosliner et al. 2008), and Mozambique (present study).

Remarks: First record for Mozambique.

Chelidonura fulvipunctata Baba, 1938

(Fig. 2g)

Material examined: PTR, 4 spcs, 15 August 2013, $\mathrm{TL}=12-22 \mathrm{~mm}$, YT 882, 883, 885, 886. PTR, 10 spcs, 26 January 2014, TL=10-15, ZMBN 94192.

Ecology: Crawling on rocks at $0.2 \mathrm{~m}$ deep.

Distribution: Hawaiian Is (Moretzsohn and Kay 1995), Guam (Carlson and Hoff 2003), Japan (Baba 1938), Australia, Papua New Guinea (Gosliner et al. 2008), and Red Sea (Yonow 2008). In the WIO it is known from Mozambique (Malaquias et al. 2016) and South Africa (Gosliner 1987; Gosliner et al. 2008).

Remarks: The species is invasive in the Mediterranean Sea where it is now established (Malaquias et al. 2016).

Chelidonura hirundinina (Quoy \& Gaimard, 1833)

(Fig. 2h) 
Material examined: ZDP, 2 spcs, 2 November 2012, $\mathrm{TL}=8 \mathrm{~mm}$, YT 646, 648. ZRP, 1 spc., 8 August 2013, $\mathrm{TL}=6 \mathrm{~mm}$, YT 588; PTR, $3 \mathrm{spcs}, \mathrm{TL}=10-15 \mathrm{~mm}, \mathrm{ZMBN}$ 94204. VIM, 1 spc., 20 May 2015, TL=2 mm, ZMBN 105152.

Ecology: Crawling on rocks in tidal reefs at $0.2 \mathrm{~m}$ deep. One specimen (ZMBN 105152) was found on algal mats near mangroves.

Distribution: Circumtropical; Hawaiian Is (Moretzsohn and Kay 1995; Gosliner et al. 2008), Guam, Pagan, Sarigan (Carlson and Hoff 2003), Fiji (Brodie and Brodie 1990), Vanuatu, Australia, Indonesia (Gosliner et al. 2008), the Philippines (Camacho-García et al. 2014), India (Sreeraj et al. 2013). WIO: Maldives, Reunión (Yonow 2012), Aldabra Atoll (Gosliner et al. 2008), Tanzania (Rudman 1973), Madagascar (Gosliner et al. 2008; Camacho-García et al. 2014), Mozambique (present study), and South Africa (Gosliner et al. 2008). Caribbean Sea (Valdés et al. 2006; Caballer et al. 2015).

Remarks: First record for Mozambique. The broad and disjunct geographical distribution of this species hints at the possible presence of multiple species under the name $C$. hirundinina. This point of view is supported by the molecular results obtained by Camacho-García et al. (2014), where two or three lineages have been distinguished.

\section{Chelidonura electra Rudman, 1970}

(Fig. 3a, b)

Material examined: VIS3, 2 spcs, 16 May 2015, TL=30, 38 mm, ZMBN 105107. VIS3, 1 spc., 18 May 2015, $\mathrm{TL}=50 \mathrm{~mm}, \mathrm{ZBMN}$ 105127. VIPP, 2 spcs, 19 May 2015, $\mathrm{TL}=21,31 \mathrm{~mm}, \mathrm{ZBMN} 105137$.

Ecology: Found crawling on coral from 7 to $10 \mathrm{~m}$ deep.

Distribution: Occurs through the IWP; Australia (Rudman 1974; Gosliner et al. 2008; Camacho-García et al. 2014), Vanuatu (Camacho-García et al. 2014), the Solomon Is (Rudman 1970, 1974; Gosliner et al. 2008), and Papua New Guinea (Gosliner et al. 2008). WIO: Mayotte, Tanzania, Maldives (Gosliner et al. 2008; Yonow 2012), Madagascar (Gosliner et al. 2008; Malaquias et al. 2009), and Mozambique (present study).

Remarks: First record for Mozambique.

\section{Chelidonura mandroroa Gosliner, 2011}

(Fig. 3c)

Material examined: VIPP, 1 spc., 19th May 2015, $\mathrm{TL}=24 \mathrm{~mm}, \mathrm{ZMBN} 105129$

Ecology: Found crawling on the reef during daytime at $6 \mathrm{~m}$ deep.
Fig. 2 a Pupa suturalis, Barra, Inhambane, shell length $=8 \mathrm{~mm}, \mathrm{ZMBN}$ 94186. b Amplustrum amplustre, Paindane, shell length $=$ ca. $10 \mathrm{~mm}, \mathrm{ZMBN}$ 94213. c Hydatina physis, Paindane, shell length =ca. $20 \mathrm{~mm}, \mathrm{ZMBN}$ 94190. d egg mass of Hydatina physis; e Micromelo undatus, Zavora, $\mathrm{TL}=25 \mathrm{~mm}, \mathrm{ZMBN}$ 94236. f Chelidonura livida, Nuarro, $\mathrm{TL}=c a$. $14 \mathrm{~mm}$. g Chelidonura fulvipunctata, Paindane, TL =12 mm, ZMBN 94192. h Chelidonura hirundinina, Paindane, TL $=13$ mm, ZMBN 94204

Distribution: IWP; Japan (Nakano 2004), Taiwan (Gosliner 2011), Indonesia, the Philippines (Gosliner et al. 2008; Gosliner 2011). WIO: Tanzania (Gosliner 2011), Madagascar (Gosliner et al. 2008; Gosliner 2011; CamachoGarcía et al. 2014), and Mozambique (present study).

Remarks: First record for Mozambique.

\section{Chelidonura punctata Eliot, 1903}

(Fig. 3d)

Material examined: VIPP, 1 spc., 13 December 2013, $\mathrm{TL}=16 \mathrm{~mm}, \mathrm{ZMBN}$ 94264. VIPP, 3 spc.,15 May 2015, $\mathrm{TL}=14-20 \mathrm{~mm}, 7 \mathrm{~m}, \mathrm{ZBMN}$ 105096. VIPP, 2 spcs, 19 May 2015, TL=14, 15 mm, ZMBN 105147.

Ecology: Found crawling on sand near coral reefs between 4 and $7 \mathrm{~m}$ deep.

Distribution: Restricted to the Indian Ocean; Thailand, Burma (Gosliner et al. 2008), India (Sreeraj et al. 2012), Maldives (Yonow et al. 2002; Gosliner et al. 2008), Chagos Archipelago (Yonow 1994; Yonow et al. 2002). WIO: Tanzania (Rudman 1973), Madagascar (Marcus and Marcus 1970), Mauritius (Yonow and Hayward 1991), Mozambique (present study), Reunion, South Africa (Yonow et al. 2002; Gosliner et al. 2008).

Remarks: First record for Mozambique. This species is similar to some colour morphs of $C$. sandrana (sometimes designated as $C$. tsurugensis; see Remarks of C. sandrana). C. punctata is not only bigger, but has larger orange-white pigment on the edge of the parapodial lobes and rear of cephalic shield, as both lobes of the tail are conspicuously developed and pointed, whereas in the C. tsurugensis-sandrana species complex the right lobe is short and stubby.

\section{Chelidonura sandrana Rudman, 1973}

(Fig. 3e)

Material examined: PTR, 1 spc., 1 February 2014, $\mathrm{TL}=10 \mathrm{~mm}, \mathrm{ZMBN} 94202$.

Ecology: Crawling on rock at $0.5 \mathrm{~m}$ deep.

Distribution: IWP; Australia, Indonesia, and Philippines (Gosliner et al. 2008), Malaysia (Gosliner et al. 2008), 

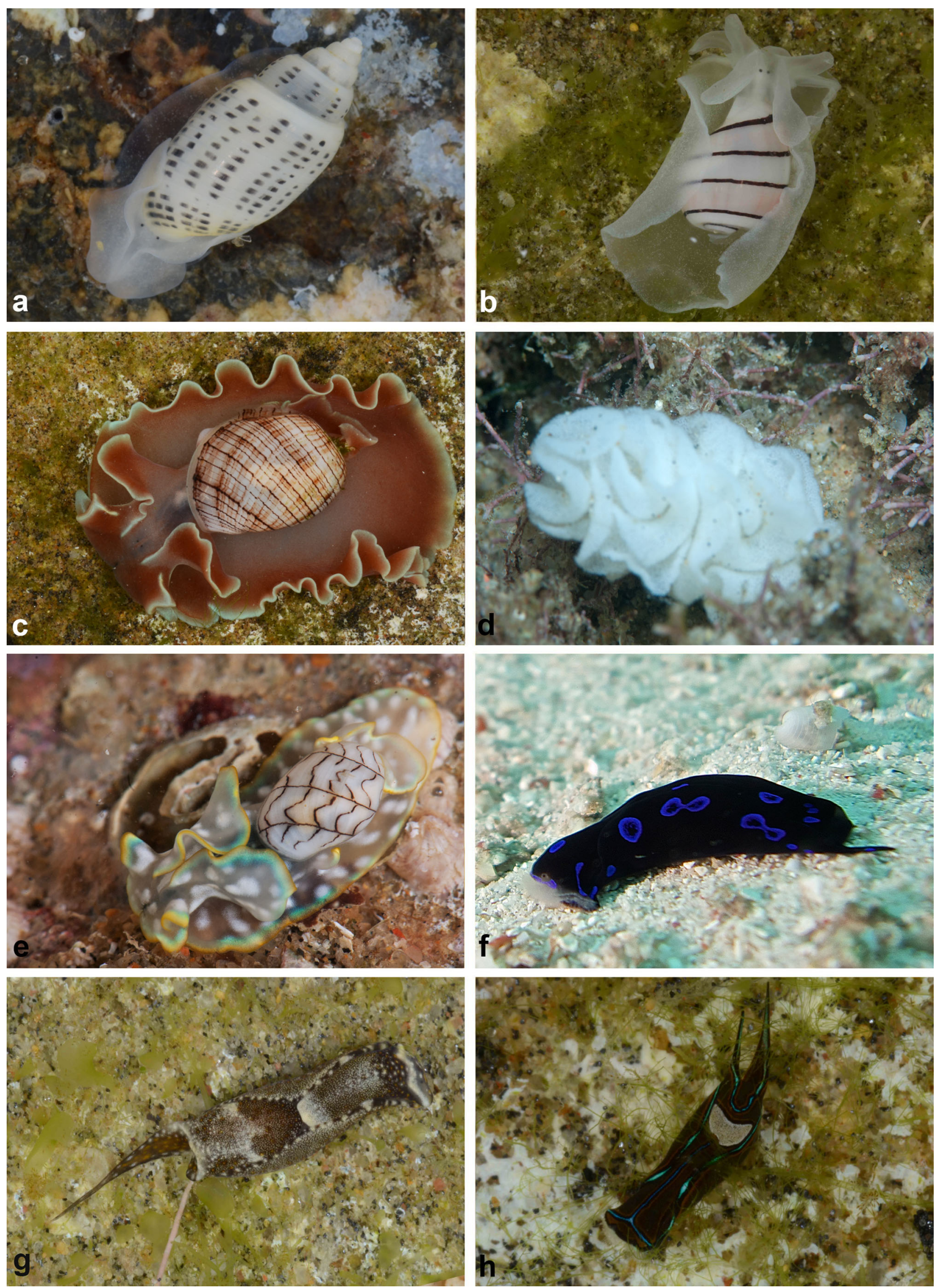
Maldives (Yonow 1994), Chagos (Yonow 1994; Yonow et al. 2002), and Red Sea (Yonow 1994, 2008). WIO: Aldabra (Gosliner et al. 2008), Tanzania (Rudman 1973), Madagascar (Gosliner et al. 2008), and Mozambique (present study).

Remarks: Chelidonura sandrana is a highly variable species depicting a considerable range of colour patterns (see Gosliner et al. 2008, 2015; Camacho-García et al. 2014). In Fig. 3e, we depict a pattern often referred to as $C$. tsurugensis Baba and Abe, 1964. Turner and Wilson (2012) after preforming mating experiments across various colour morphs of the Chelidonura tsurugensis-sandrana species complex have suggested that until a systematic revision of Chelidonura is available "the use of the name $C$. tsurugensis should be restricted to Japan, and elsewhere the yellow-spotted colour form should be referred to as $C$. sandrana". Additionally, CamachoGarcía et al. (2014) provided phylogenetic evidence for the existence of several species within the $C$. tsurugensis-sandrana species complex and have showed the difficulties of a taxonomy based in colour morphs in this group, as specimens ranging from those having dark background with yellow spots to those completely black, or nearly white with scattered orange dots can be, molecularly, completely the same.

Genus Odontoglaja Rudman, 1978

Odontoglaja mosaica Gosliner, 2011

(Fig. 3f, g)

Material examined: POC, 2 spcs, 8 May 2014, TL $=10$ $16 \mathrm{~mm}$, YT 119. NEL, $1 \mathrm{spc}$., 30 May 2014, TL $=5 \mathrm{~mm}$, YT 1285.

Ecology: Crawling on rocks in subtropical and tropical reefs between 9 and $15 \mathrm{~m}$ deep.

Distribution: Red Sea (Yonow 2008 as O. guamenisis; Gosliner et al. 2008 as Odontoglaja sp.). WIO: Madagascar, South Africa (Gosliner et al. 2008 as Odontoglaja sp.; Gosliner 2011), and Mozambique (present study).

Remarks: First record to Mozambique. Odontoglaja mosaica was described from Madagascar by Gosliner (2011) and is chromatically very similar to $O$. guamensis. Both species are difficult to distinguish based on their external appearance, but Gosliner (2011) suggested that $O$. mosaica is the only species present in the Western Indian Ocean, whereas O. guamensis is restricted to the Western Pacific.

Genus Philinopsis Pease, 1860

Philinopsis orientalis (Baba, 1949)

(Fig. 3h)

Material examined: PTR, 2 spcs, 15 August 2013, $\mathrm{TL}=14,28 \mathrm{~mm}$, YT 881, YT 884.
Fig. 3 a Chelidonura electra, Vamizi I., TL $=50 \mathrm{~mm}$, ZMBN 105127. b Chelidonura electra, Vamizi I., TL $=31 \mathrm{~mm}, \mathrm{ZMBN} 105127$, this specimen has shorter caudal lobes. c Chelidonura mandroroa, Vamizi I., $\mathrm{TL}=24 \mathrm{~mm}, \mathrm{ZMBN}$ 105129. d Chelidonura punctata, Vamizi I., $\mathrm{TL}=16 \mathrm{~mm}, \mathrm{ZMBN}$ 94264. e Chelidonura sandrana, Paindane, $\mathrm{TL}=10 \mathrm{~mm}, \mathrm{ZMBN}$ 94202. f Odontoglaja mosaica, Ponta do Ouro, $\mathrm{TL}=$ ca. $14 \mathrm{~mm}$, YT 1196. $\mathbf{g}$ view of the foot of Odontoglaja mosaica depicted in $\mathbf{f} . \mathbf{h}$ Philinopsis orientalis, Paindane, TL $=28 \mathrm{~mm}$, YT 881

Ecology: Found crawling under a rock at $0.3 \mathrm{~m}$ deep. It exudes a dark yellow chemical when disturbed.

Distribution: Indo-Pacific; Hawaiian Is (Kay 1979 as Aglaja orientalis; Moretzsohn and Kay 1995), Marshall Is (Camacho-García et al. 2014), Guam (Carlson and Hoff 2003 as Aglaja? orientalis), Japan, New Caledonia, Korea (Gosliner et al. 2008), and the Philippines (Gosliner et al. 2008; Camacho-García et al. 2014). WIO: Mozambique (present study) and South Africa (Gosliner et al. 2008).

Remarks: First reference for Mozambique; second for WIO.

\section{Philinopsis pilsbryi (Eliot, 1900)}

(Fig. 4a, b)

Material examined: VISG, 1 spc., 16 May 2015, $\mathrm{TL}=36 \mathrm{~mm}, \mathrm{ZMBN}$ 105108. VISG, 1 spc., 21 May 2015, $\mathrm{TL}=22 \mathrm{~mm}, \mathrm{ZMBN} 105153$.

Ecology: Found crawling on sand near seagrass.

Distribution: Indo-Pacific; Hawaii (Moretzsohn and Kay 1995), Marshall Is, Guam, Palau (Gosliner et al. 2008), Vanuatu, Fiji (Brodie and Brodie 1990), Australia (CamachoGarcía et al. 2014), Papua New Guinea (Domínguez et al. 2007), Indonesia, the Philippines, and Malaysia (Gosliner et al. 2008), Red Sea (Yonow 2008, as P. reticulata). WIO: Madagascar (Gosliner et al. 2008) and Mozambique (present study).

Remarks: First record for Mozambique. This is a variable species depicting a range of colour patterns varying from darker forms with a thick, dark reticulate line delimiting whitish polygons (Fig. 4a) to lighter forms with a mushy, finer reticulated dark line (Fig. 4 b).

Philinopsis reticulata (Eliot, 1903)

(Fig. 4c)

Material examined: VISG, 1 spc., 21 May 2015, $\mathrm{TL}=44 \mathrm{~mm}, \mathrm{ZMBN} 105159$.

Ecology: Crawling on sand near seagrass at $2 \mathrm{~m}$ deep. 

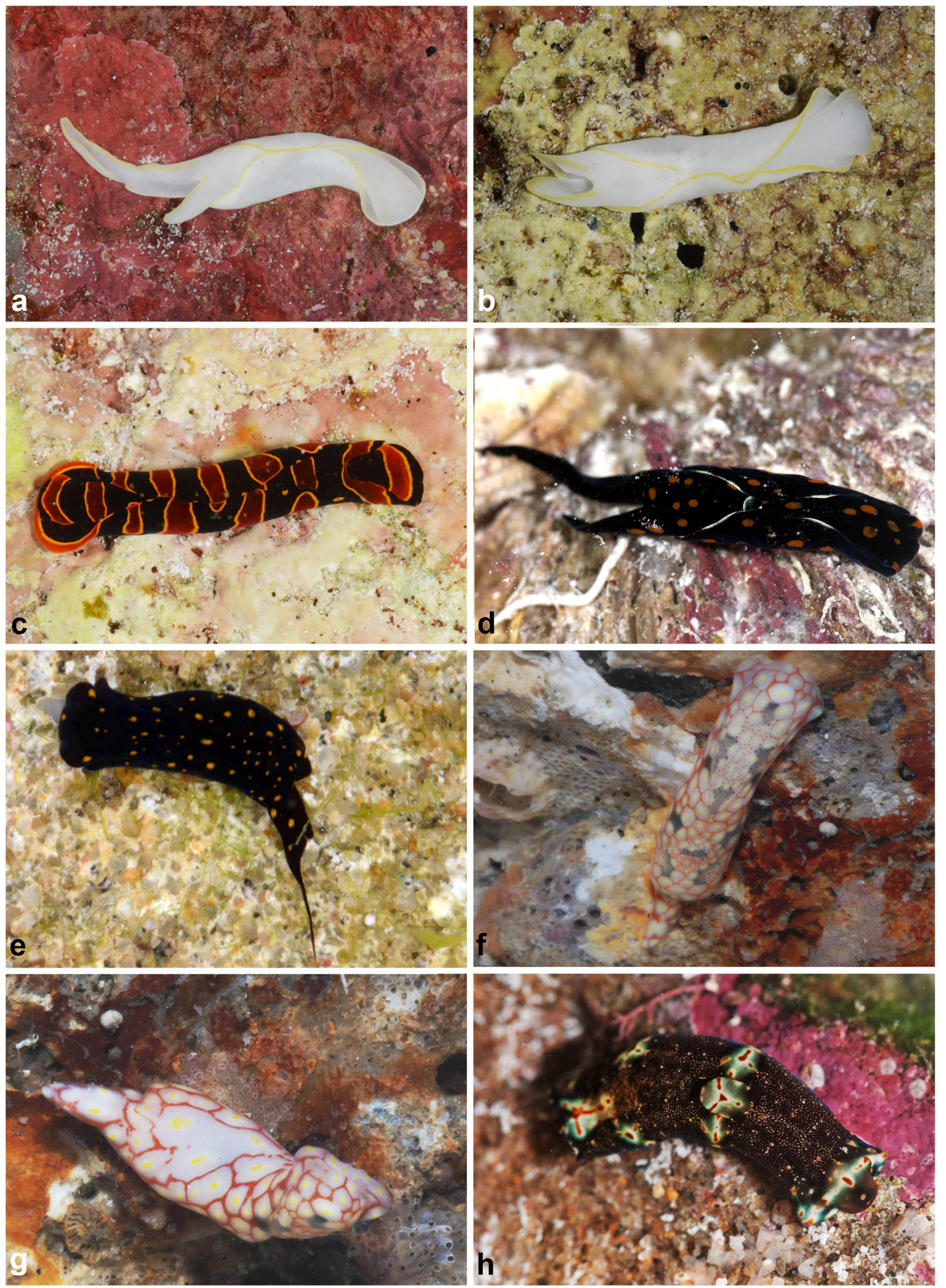
Distribution: Red Sea (Yonow 2008) and WIO. Madagascar, Tanzania, South Africa, (Gosliner et al. 2008), and Mozambique (Branch et al. 2008; King and Fraser 2014).

Remarks: According to Gosliner et al. (2008) the records from western Australia and the Pacific Ocean require further confirmation. Our specimen released a yellow fluid when disturbed.

\section{Philinopsis speciosa Pease, 1860}

(Fig. 4d-g)

Material examined: BLE, 1 spc., 25 August 2012, $\mathrm{TL}=30 \mathrm{~mm}$, YT 576; BLE, $1 \mathrm{spc}$., 22 October 2014, $\mathrm{TL}=52 \mathrm{~mm}$ (not collected but measured under water); VIS, 4 spcs, 12 December 2013, TL =37-48 mm, YT 1031-1034.

Ecology: Found around seagrass between 1 and $5 \mathrm{~m}$ deep in subtropical and tropical waters.

Distribution: Indo-Pacific; Galapagos (Gosliner et al. 2008; Camacho-García et al. 2014), Panama (Gosliner et al. 2008), Hawaiian Is (Moretzsohn and Kay 1995; Gosliner et al. 2008), Australia (Burn 2006 as $P$. cyanea), Indonesia (Gosliner et al. 2008), Maldives (Yonow 1993), and Red Sea (Yonow 1994, 2008). WIO: Tanzania (Rudman 1972a), Mozambique (King and Fraser 2014; Gosliner 1987 as P. cyanea; von Martens 1879 as Doridium cyaneum and Doridium nigrum, both as new species), and South Africa (Gosliner 1987 as P. cyanea; Gosliner et al. 2008).

Remarks: Gosliner et al. (2008: 39, 2015: 45) considered this species to be highly variable in colour with several distinct morphs regarded as conspecific. Von Martens (1879) has described two species from Mozambique, namely Doridium cyaneum, regarded presently as a synonym of $P$. speciosa (Gosliner et al. 2008; Yonow 2012; Bouchet 2015b) and Doridium nigrum. The latter species is hardly mentioned in the literature and is not even listed in the World Register of Marine Species (Bouchet 2015a; Gofas and Bouchet 2015). However, the total length of the type specimen, length of the head-shield, and colour pattern with a dark background, yellow and orange blotches and lines scattered over the body, and indigo blue margins (von Martens 1879: 738) matches one of the known morphotypes of $P$. speciosa (see Fig. 4d; Gosliner et al. 2008), and therefore, we regard the name Doridium nigrum as a junior synonym of $P$. speciosa.

Yet, we do not discard that a future systematic review of the genus Philinopsis, integrating morphological and molecular data, might reveal the presence of several species within the $P$. speciosa colour morphs. Several recent works using
Fig. 4 a Philinopsis pilsbryi, Vamisi I., TL $=36$ mm, ZMBN 105108. b Philinopsis pilsbryi, Vamisi I., TL $=22 \mathrm{~mm}$, ZMBN 105153. c Philinopsis reticulata, Vamisi I., TL $=44 \mathrm{~mm}, \mathrm{ZMBN} 105159$. d-g Philinopsis speciosa. d Barra Lagoon, Inhambane, $\mathrm{TL}=30 \mathrm{~mm}$, YT 576. f Vamizi, TL $=44 \mathrm{~mm}$, YT 1032. g Vamizi, TL $=48 \mathrm{~mm}$, YT 1031. h Philinopsis gardineri, Nuarro, TL $=22 \mathrm{~mm}$, YT 1281

molecular phylogenetics have showed that species of sea slugs regarded as highly variable in colour were in fact complexes of several species (e.g. Ornelas-Gatdula and Valdés 2012 [Philinopsis]; Carmona et al. 2014b [Spurilla]), but there are also opposite examples; for instance, Malaquias et al. (2016) have confirmed that distinct colour morphs of Chelidonura fulvipunctata are conspecific.

\section{Philinopsis gardineri (Eliot, 1903)}

(Fig. 4h)

Material examined: BLE, 3 spcs, 26 August 2012, $\mathrm{TL}=11,22 \mathrm{~mm}$, YT574, 575. NEL, 1 spc., 30 May 2014, $\mathrm{TL}=22 \mathrm{~mm}, \mathrm{YT} 1281$.

Ecology: Found around seagrass and under rocks on tropical coral reef between 1 and $9 \mathrm{~m}$ deep.

Distribution: IWP; Marshall Is (Johnson and Boucher 1983), Guam (Camacho-García et al. 2014), Fiji (Brodie and Brodie 1990; Camacho-García et al. 2014), Australia (Camacho-García et al. 2014), New Guinea, Indonesia, Guam, the Philippines (Gosliner et al. 2008). WIO: Maldives, Tanzania, Madagascar (Gosliner et al. 2008), and Mozambique (present study).

Remarks: First record to Mozambique.

Family BULLIDAE Gray, 1827

Genus Bulla Linnaeus, 1758

\section{Bulla ampulla Linnaeus, 1758}

(Fig. 5a-c)

Material examined: BLE, 4 spcs, 6 December 2012, $\mathrm{TL}=38-48 \mathrm{~mm}$, YT 701-704. VISG, 3 spcs, 12 December 2013, TL $=50-78 \mathrm{~mm}$, YT 1026 (1 spc.) \& ZMBN 94274 (2 spcs). BLE, 7 spcs, 23 January 2014, TL $=30-50 \mathrm{~mm}, \mathrm{ZMBN}$ 94170. PTR, 12 spcs, 2 February 2014, TL $=20-40 \mathrm{~mm}$, ZMBN 94214 [together with $B$. orientalis]. VIM, 20 May 2015, 1 spc. TL=40 mm (shell), ZBMN 105151.

Ecology: Most specimens were found between 0.2 and $5 \mathrm{~m}$ deep. Either buried on sand among seagrass during daytime or crawling on sand around reef rocks at night.

Distribution: IWP; for a detailed distribution see Malaquias and Reid (2008). WIO: Kenya, Tanzania, 

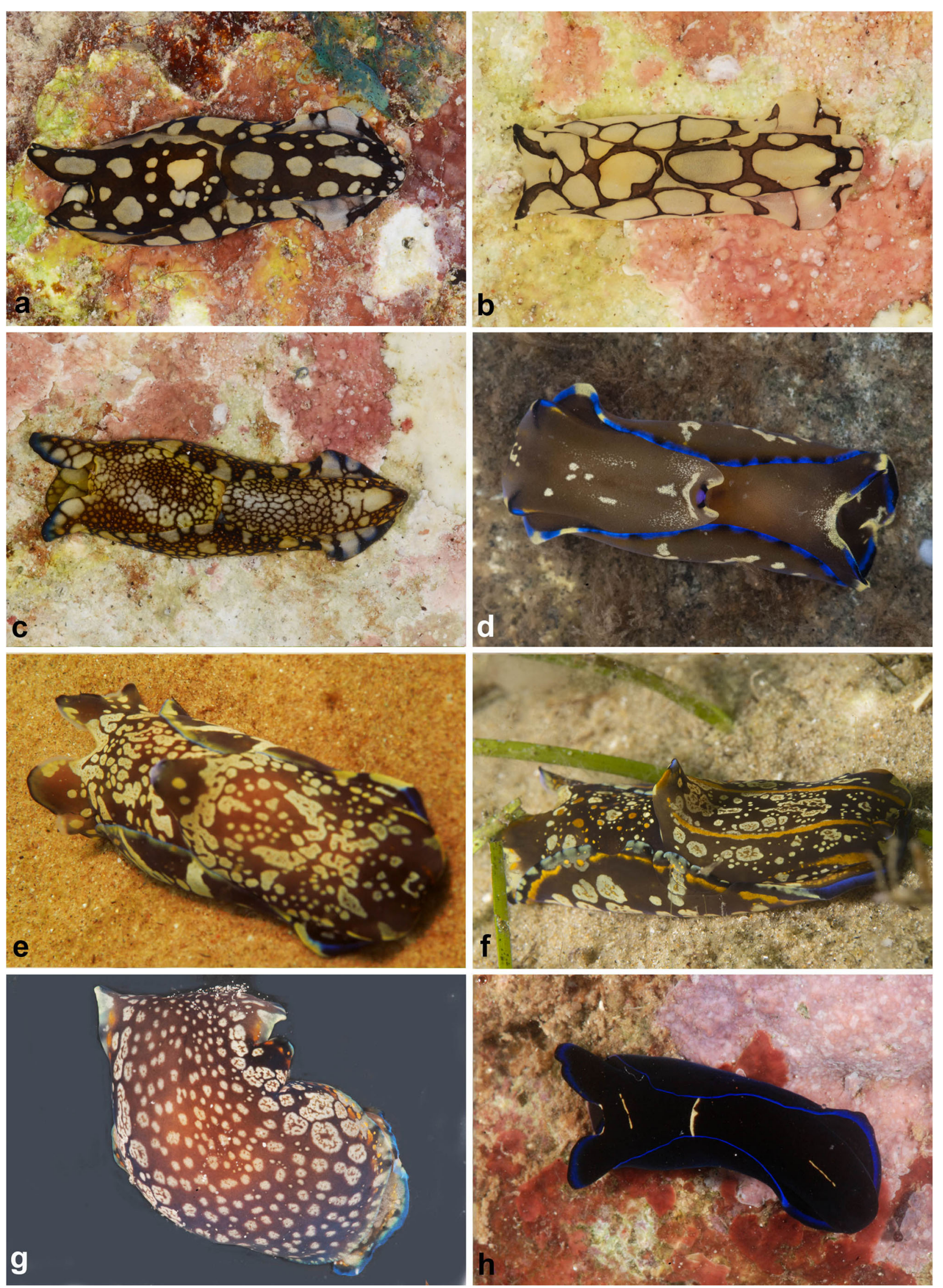
Mayotte, Seychelles and Reunion, Mozambique, South Africa (Malaquias and Reid 2008), Mauritius, Madagascar (Yonow and Hayward 1991; Malaquias and Reid 2008). In Mozambique it has been recorded to the Quirimbas Archipelago, Mozambique Island, Nacala, Bazaruto, Inhambane, and Inhaca I. (MacNae and Kalk 1958, 1962; Malaquias and Reid 2008).

Remarks: This species shows chromatic variability that is particularly noticeable on the cephalic shield. This region of the body can have different intensities of brownish pigment and patches of small white dots, but typically depicts a wide $\mathrm{W}$-shaped mark between the eyes and the anterior margin (see Fig. 5a-c; Malaquias and Reid 2008). Another distinguishable feature of B. ampulla are the much shorter and less rolled cephalic tentacles that look almost absent when compared to any other species in the genus (see for comparison Fig. 5a-c B. ampulla and Fig. 5d-f B. orientalis).

\section{Bulla orientalis Habe, 1950}

(Fig. 5d-g)

Material examined: ZDP, 2 spcs., 14 October 2012, $\mathrm{TL}=18 \mathrm{~mm}$, YT 627. PAN, 3 December 2013, 5 spcs, $\mathrm{TL}=12-22 \mathrm{~mm}$, YT 962-965. VISG, 1 spc., 12 December 2013, TL $=9$ mm, YT 1020. PTR, 1 spc., 1 February 2014, $\mathrm{TL}=25 \mathrm{~mm}, \mathrm{ZMBN} 94200$. PTR, 12 spcs, 2 February 2014, $\mathrm{TL}=20-40 \mathrm{~mm}, \mathrm{ZMBN} 94214$ [together with B. ampulla].

Ecology: Tropical and subtropical reefs often on rocks covered with green algae; found both crawling at night and in the daytime.

Distribution: See Malaquias and Reid (2008) for a detailed distribution. WIO: Andaman Is, Maldives, Mauritius, Seychelles, Tanzania, Madagascar, and South Africa (Gosliner et al. 2008; Malaquias and Reid 2008); Mozambique (present study).

Remarks: This IWP species has two main morphotypes; one with a dotted shell occurring in the West Pacific and the other with a shell mottled with brown-reddish dots restricted to the Indian Ocean. It can be easily confused with Bulla vernicosa, but the latter species is only present in the western and central regions of the Pacific Ocean (see Malaquias and Reid 2008 for a discussion).

The specimen illustrated in Fig. $5 \mathrm{~g}$ is chromatically distinct and the shell is more elongated and lighter than $B$. orientalis. It is not possible at this point to tease apart whether these differences reflect a distinct taxonomic identity or are ontogenetic since the specimen is small and likely a juvenile.

Family COLPODASPIDIDAE Oskars, Bouchet \& Malaquias, 2015
Fig. 5 a-c morphs of Bulla ampulla. a Vamizi, $\mathrm{TL}=50 \mathrm{~mm}$, YT 1026. b Barra Lagoon, Inhambane, $\mathrm{TL}=48 \mathrm{~mm}$, YT 702. $\mathbf{c}$ Paindane, $\mathrm{TL}=c a$. $35 \mathrm{~mm}$, ZMBN 94214. d-g morphs of Bulla orientalis. d Zavora, $\mathrm{TL}=18 \mathrm{~mm}$, YT 627. e Pemba, shell length $=10 \mathrm{~mm}$, YT 962. f Paindane, $\mathrm{TL}=c a .25 \mathrm{~mm}, \mathrm{ZMBN}$ 94214. g Vamizi, TL $=9 \mathrm{~mm}$, YT 1020. h Colpodaspis thompsoni, Ponta do Ouro, TL $=4 \mathrm{~mm}$, YT 1026

Genus Colpodaspis M. Sars, 1870

Colpodaspis thompsoni G. H. Brown, 1979

(Fig. 5h)

Material examined: POB, 1 spc., 9 May 2014, $\mathrm{TL}=4 \mathrm{~mm}$, YT 1026.

Ecology: Found crawling on a rock at $18 \mathrm{~m}$ deep.

Distribution: IWP; Fiji (Brodie and Brodie 1990), Guam (Carlson and Hoff 2003), Hawaiian Is (Gosliner et al. 2008), Red Sea (Heller and Thompson 1983; Yonow 2008). WIO: Tanzania (type locality, Brown 1979), Madagascar (Gosliner et al. 2008), and Mozambique (present study).

Remarks: First record to Mozambique.

Family GASTROPTERIDAE Swainson, 1840

Genus Sagaminopteron Tokioka \& Baba, 1964

Sagaminopteron psychedelicum Carlson \& Hoff, 1974

(Fig. 6a)

Material examined: TMR, $1 \mathrm{spc}$. (photographed only), 7th August 2014.

Ecology: Occurs in tropical coral reefs often between 10 and $15 \mathrm{~m}$ deep. Observed in high abundances between August and October 2014.

Distribution: IWP; Hawaii, Guam (Carlson and Hoff 2003; Gosliner et al. 2008), Okinawa, New Guinea (Gosliner et al. 2008), Australia (Vonnemann et al. 2005), Fiji (Brodie and Brodie 1990; Gosliner et al. 2008), the Philippines (Gosliner et al. 2008), India (Apte 2009), Red Sea (Yonow 2008). WIO Madagascar (Gosliner et al. 2008; Malaquias et al. 2009; Eilertsen and Malaquias 2015), Reunion, Tanzania (Gosliner et al. 2008), and Mozambique (present study).

Remarks: First record for Mozambique.

Genus Siphopteron Gosliner, 1989

Siphopteron sp.

(Fig. 6b)

Material examined: PHP, 1 spc., 4 December 2013, $\mathrm{TL}=3 \mathrm{~mm}$, YT 971 .

Ecology: Found under a rock at $1 \mathrm{~m}$ deep. 

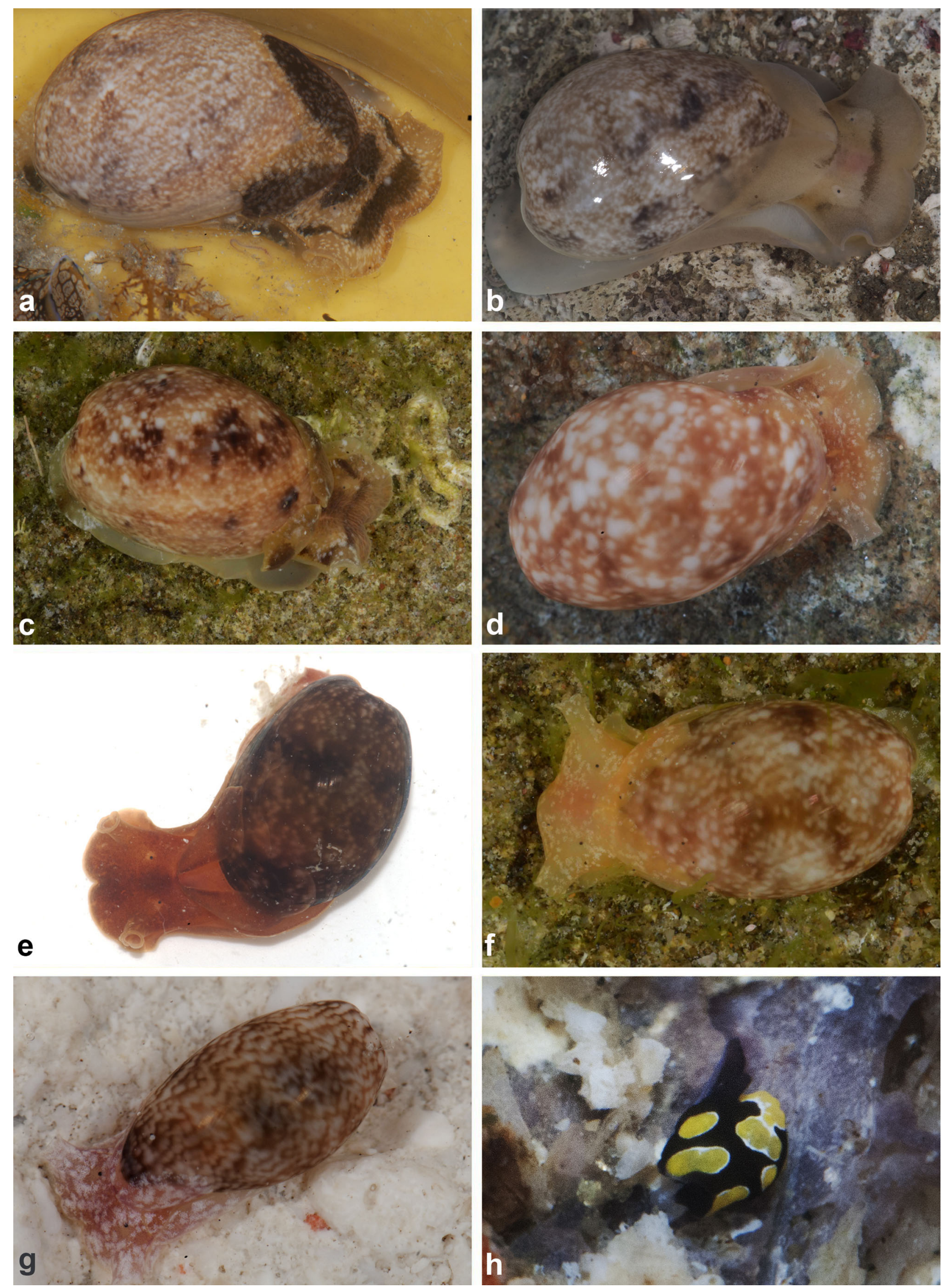
Distribution: Mozambique (present study).

Remarks: This animal appears to correspond to an undescribed species, but additional specimens are necessary to soundly compare with other congeneric species from the Indo-Pacific.

Family HAMINOEIDAE Pilsbry, 1895

Genus Smaragdinella A. Adams, 1848

Smaragdinella calyculata (Broderip \& G. B. Sowerby I, 1829)

(Fig. 6c)

Material examined: ZDP, 1 spc., 14 October 2012, $\mathrm{TL}=7 \mathrm{~mm}$, YT 607 .

Distribution: IWP; Hawaiian Is (Moretzsohn and Kay 1995; Gosliner et al. 2008), Marshall Is (Johnson and Boucher 1983), New Caledonia, Solomon Is (Héros et al. 2007), Papua New Guinea, Guam, Japan (Gosliner et al. 2008). WIO: Mauritius (Yonow and Hayward 1991), Mozambique (present study), and South Africa (Gosliner 1987).

Ecology: Found on a tidal reef at $0.3 \mathrm{~m}$ deep during low tide. Remarks: First record for Mozambique.

Genus Haminoea Turton \& Kingston [in Carrington], 1830 Haminoea cymbalum (Quoy \& Gaimard, 1832)

(Fig. 6d)

Material examined: ZDP, one spc., 2 November 2012, $\mathrm{TL}=18 \mathrm{~mm}$, YT 647. PTR, three spcs, 15 August 2013, $\mathrm{TL}=12-14 \mathrm{~mm}$, YT 891, 893, 894.

Ecology: Found in tropical and sub-tropical tidal reefs between 0.2 and $0.5 \mathrm{~m}$.

Distribution: Indo-Pacific; Hawaiian Is (Moretzsohn and Kay 1995), Marshall Is (Johnson and Boucher 1983), Guam, Tinian, Rota (Carlson and Hoff 2003), Japan (Gosliner et al. 2008), Fiji (Brodie and Brodie 1990), Australia (Marshall and Willan 1999; Gosliner et al. 2008), Indonesia (Gosliner et al. 2008), India (Apte 2009), Maldives (Yonow 2012), and Red Sea (Heller and Thompson 1983). WIO: Madagascar (Gosliner et al. 2008) and Mozambique (von Martens 1879; Gosliner et al. 2008).

\section{Haminoea natalensis (Krauss, 1848).}

(Fig. 6e, f)

Material examined: ZDP 10 spcs, 14 October 2012, $\mathrm{TL}=7-14 \mathrm{~mm}$, YT 633, YT 634, YT 636, YT 638, YT 639. ZDP, 2 spcs, TL=7-9 mm, YT 54, YT 57. ZRP, 1 spc., 09 October 2013, TL $=5 \mathrm{~mm}$, YT 934.
Fig. 6 a Sagaminopteron psychedelicum, Bazaruto. b Siphopteron sp., Zavora, TL $=7 \mathrm{~mm}$, YT 607. c Smaragdinella calyculata, Zavora, $\mathrm{TL}=7 \mathrm{~mm}$, YT 607. d Haminoea cymbalum, Zavora, TL $=18 \mathrm{~mm}$, YT 647. e Haminoea natalensis, Zavora, TL $=14 \mathrm{~mm}$, YT 634. f Haminoea natalensis, Zavora, TL $=12 \mathrm{~mm}$, YT 636. g Phanerophthalmus $\mathrm{cf}$. cylindricus, Paindane, TL $=10 \mathrm{~mm}, \mathrm{ZMBN}$ 94193. h view of the foot of previous specimen

Ecology: Found at night in tidal reefs between 0.3 and $3 \mathrm{~m}$ deep.

Distribution: IWP; Hawaiian Is (Kay 1979 as Haminoea crocata; Gosliner et al. 2008), Papua New Guinea, the Philippines (Gosliner et al. 2008). WIO: Mauritius, Seychelles (Bergh 1901), Madagascar (Gosliner 1987; Gosliner et al. 2008), Mozambique (Bergh 1901; Gosliner 1987), and South Africa (Bergh 1901; Kilburn and Rippey 1982; Gosliner 1987; Gosliner et al. 2008).

Remarks: Preliminary molecular studies (Oskars and Malaquias, work in progress) indicate that most likely there are several species in the IWP "hidden" under the name $H$. natalensis. Typically, specimens mottled with brownish/ greenish dots in the region are ascribed to this species (e.g. Gosliner 1987; Gosliner et al. 2008). Figure 6e and f depict two different colour morphos; whether this is related to different ontogenetic stages, different food sources, or different species, it remains to be thoroughly tested with morphological and DNA data.

Genus Phanerophthalmus A. Adams, 1850

Phanerophthalmus ef. cylindricus (Pease, 1861)

(Fig. 6g, h)

Material examined: PTR, 1 spc., 26 January 2014, $\mathrm{TL}=10 \mathrm{~mm}, \mathrm{ZMBN} 94193$.

Ecology: Found crawling on a rock at $0.5 \mathrm{~m}$ deep.

Distribution: Hawaiian Is (Moretzsohn and Kay 1995) and Mozambique (present study).

Remarks: This is a difficult genus with a poorly known taxonomy and at present a global systematic review is under preparation (Austin, Gosliner and Malaquias, work in progress). We here tentatively identify our specimen as $P$. cylindricus based on chromatic similarities with specimens from Hawaii, the type locality of the species and so far the only region where it was previously reported. The presence of this species in Mozambique may represent a remarkable westward extension, but Gosliner et al. (2008) has previously 

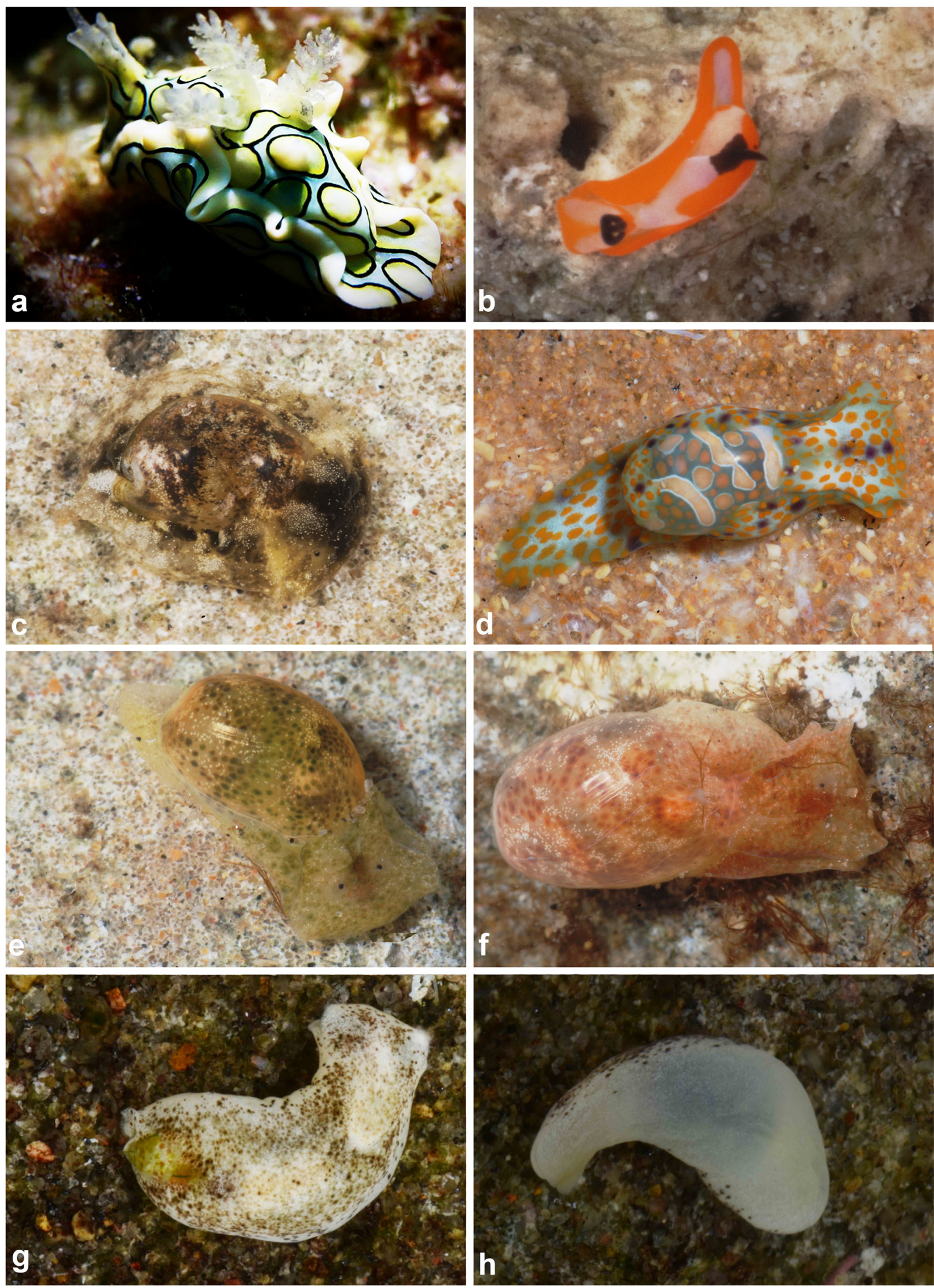
mentioned that $P$. cylindricus is possibly more widespread. In fact, the specimen illustrated by Gosliner et al. (2008) as Phanerophthalmus sp. from the Philippines could well be a juvenile of $P$. cylindricus. First record for Mozambique and the WIO.

Phanerophthalmus smaragdinus (Rüppell \& Leuckart, 1830)

(Fig. 7a, b)

Material examined: NRB, 8 June 2014, 1 spc., $\mathrm{TL}=29 \mathrm{~mm}$, YT 1329. PTR, 2 February 2014, 1 spc., $\mathrm{TL}=10 \mathrm{~mm}, \mathrm{ZMBN} 94216$.

Ecology: Found in tropical subtidal and tidal reefs between 0.5 and $1 \mathrm{~m}$ deep. Hides under rocks during the day and crawls at night.

Distribution: IWP; Indonesia to Papua New Guinea, the Philippines, Vanuatu (Moretzsohn and Kay 1995), Fiji (Brodie and Brodie 1990), Guam (Carlson and Hoff 2003), Japan (Nakano 2004), India (Apte 2009; Narayana and Mohanraju 2013). Red Sea (Yonow 2000, 2008 as $P$. olivaceus). WIO: Seychelles, Madagascar (Gosliner et al. 2008), Mozambique (present study) and South Africa (Gosliner 1987; Gosliner et al. 2008).

Remarks: First record for Mozambique. The lighter colour pattern of the specimen depicted in Fig. 7b is likely due to its smaller size. Yonow $(2000 ; 2008)$ has identified similar specimens from the Red Sea as P. olivaceus (Yonow 2000, 2008), whereas all previous records of this morphotype in the Western Indian Ocean (Gosliner 1987; Gosliner et al. 2008) were identified as $P$. smaragdinus. This disagreement is not surprising since, as highlighted above, the taxonomy and nomenclature of this genus is little understood and hampered by poor original descriptions.

Phanerophthalmus cf. albocollaris Heller \& Thompson, 1983

(Fig. 7c)

Material examined: ZDP, 1 spc., 14 October 2010, $\mathrm{TL}=32 \mathrm{~mm}$, YT 629. ZRP, 1 spc., 3 February 2014, $\mathrm{TL}=9 \mathrm{~mm}, \mathrm{ZMBN} 94242$.

Ecology: Found active at night and in the daytime in tidal reefs between 0.2 and $2 \mathrm{~m}$ deep.

Distribution: IWP; Papua New Guinea, Indonesia, the Philippines, Guam, Japan, Hawaii (Gosliner et al. 2008), Red Sea (Heller and Thompson 1983; Yonow 2008). WIO: Mozambique (present study).
Fig. 7 a Phanerophthalmus smaragdinus, Nacala, TL $=29 \mathrm{~mm}$, YT 1329. b Phanerophthalmus smaragdinus, Paindane, TL $=10 \mathrm{~mm}$, ZMBN 94216. c Phanerophthalmus cf. albocollaris, Zavora, $\mathrm{TL}=9 \mathrm{~mm}, \mathrm{ZMBN}$ 94242. d Phanerophthalmus sp., Zavora, $\mathrm{TL}=5 \mathrm{~mm}$, YT 1418. e, f Philine aperta, Barra, Inhambane, $\mathrm{TL}=60 \mathrm{~mm}, \mathrm{ZMBN}$ 94169. g Philine cf. elegans, Paindane, $\mathrm{TL}=8$, $10 \mathrm{~mm}, \mathrm{ZMBN}$ 94218. h Philine rubrata, Zavora, TL $=4 \mathrm{~mm}$, YT 400

Remarks: Based on the general colour pattern we tentatively identified our specimens as $P$. cf. albocollaris, but typically this species has a conspicuous inverted "W"-mark on the rear part of the cephalic shield that is not visible in the specimens from Mozambique. First record for Mozambique and WIO.

\section{Phanerophthalmus sp.}

(Fig. 7d)

Material examined: ZRP, 1 spc., 10 October 2014, $\mathrm{TL}=5 \mathrm{~mm}$, YT 1418 .

Ecology: Found at $1 \mathrm{~m}$ deep crawling on sand.

Distribution: Mozambique, likely more widespread through the Indo-Pacific.

Remarks: The lack of a systematic revision of the genus Phanerophthalmus makes it difficult to ascertain the taxonomic value of small differences in the colour pattern of these slugs. Our specimen matches the one depicted by Gosliner et al. (2008: 29; 2015: 32, for two localities along the IWP) and by Nakano (2004: 29 for Japan), both identified to genus only, but they could also be juveniles of $P$. cylindricus (see Figs. $6 \mathrm{~g}$ and $7 \mathrm{~d}$ ).

Family PHILINIDAE Gray, 1850 (1815)

Genus Philine Ascanius, 1772

Philine aperta (Linnaeus, 1767)

(Fig. 7e, f)

Material examined: BLE, 2 spcs, 23 January 2014, $\mathrm{TL}=60 \mathrm{~mm}, \mathrm{ZMBN}$ 94169; BLE, 25 January 2014, 3 spcs, $\mathrm{TL}=50 \mathrm{~mm}, \mathrm{ZMBN} 94185$.

Ecology: Found buried in sandy-mud bottoms in an estuarine area at $0.5 \mathrm{~m}$ deep.

Distribution: Between Mozambique and South Africa (Branch et al. 2008; Price et al. 2011).

Remarks: This species was until recently regarded as broadly distributed across the IWP, but based on the study of the anatomy of specimens from several localities Price et al. (2011) concluded that $P$. aperta is restricted to the Western Indian Ocean countries of Mozambique and South Africa. 

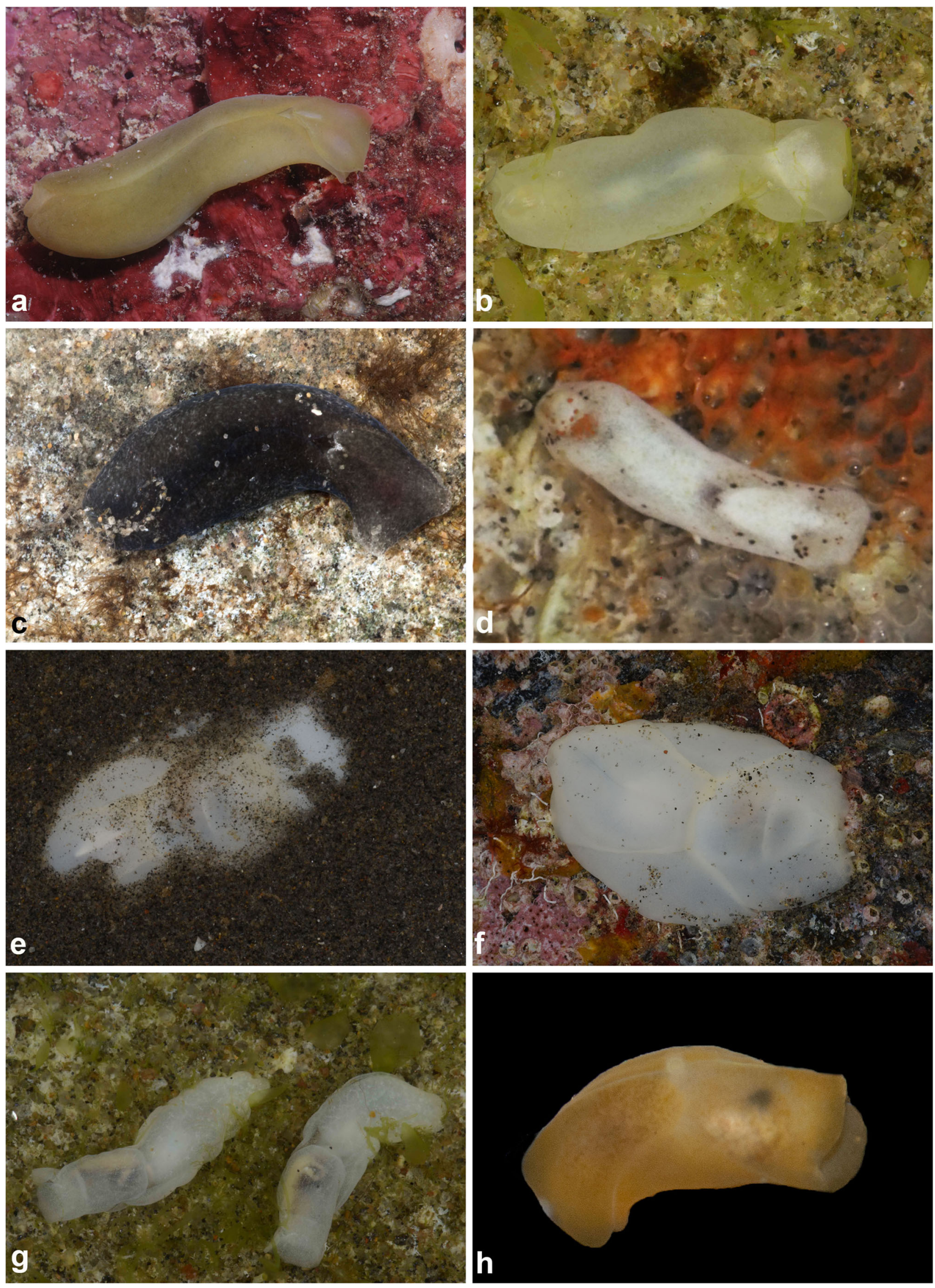
Table 2 Species recorded in the literature for Mozambique not found during our surveys

\begin{tabular}{llll}
\hline Family & Species & Location & Reference \\
\hline Acteonidae & Pupa solidula (Linnaeus, 1758) & Mozambique & Robin (2008) \\
Aglajidae & Chelidonura varians Eliot, 1903 & Inhaca Island & Macnae and Kalk (1958) as Chelidonura velutina \\
Haminoeidae & Aliculastrum cylindricum (Helbling, 1779) & Inhaca Island & MacNae and Kalk (1958) as Atys cylindrica \\
Haminoeidae & Haminoea petersi (Martens, 1879) & Quirimbas Archipelago & von Martens (1879); as Haminea petersi \\
Hydatinidae & Hydatina zonata (Lightfoot, 1786) & Inhambane and Inhaca Island & von Martens (1879), Macnae and Kalk (1962); \\
& & & both as Hydatina velum \\
Philinidae & Philine berghi E. A. Smith, 1910 & Quirimbas Archipelago & von Martens (1879); as Philine capensis \\
Scaphandridae & Scaphander centa (Okutani, 1987) & Mozambique & Robin (2008) [this is probably a deep-sea species]
\end{tabular}

Due to the current fluid taxonomic status of philinid snails (see Oskars et al. 2015) we here ascribe all our three species of philinids to the genus Philine.

\section{Philine cf. elegans Bergh, 1905}

(Fig. 7g)

Material examined: PTR, 4 spcs, 2nd February 2014, $\mathrm{TL}=8-10 \mathrm{~mm}, \mathrm{ZMBN} 94218$.

Ecology: Found on a tropical tidal reef at $0.5 \mathrm{~m}$ deep crawling on a rock at night.

Distribution: This species was only known from the West Pacific; the Philippines (Price et al. 2011), Indonesia (Price et al. 2011; Gosliner et al. 2008), and Papua New Guinea (Gosliner et al. 2008). WIO: Mozambique (present study).

Remarks: The species $P$. elegans was until now only known from the western Pacific. Our specimens resemble those illustrated by Gosliner et al. (2008: 35; 2015: 40) and Price et al. (2011: 6, Fig. 2d), but are also similar to those depicted by Gosliner et al. (2008: 37, Philine spc. 3 and 2015: 42 as Philine spc. 4) from the Philippines. Many IWP species of Philine have been poorly described based only on conchological features, creating much confusion in the literature (Price et al. 2011). Thus, we do not discard that future studies will reassign our specimens to a different taxon. A sound taxonomic revision of these snails is lacking, and recently the systematics of philinid heterobranchs went through dramatic changes at both generic and familial levels (Oskars et al. 2015).

\section{Philine rubrata Gosliner, 1988}

(Fig. 7h)

Material examined: ZA51, 1 spc., 27 May 2012, $\mathrm{TL}=4 \mathrm{~mm}$, YT 400 .

Ecology: Found on the green algae Ulva sp. at $12 \mathrm{~m}$ deep.
Distribution: Widespread in the tropical IWP; Australia (Burn 2006), Papua New Guinea, the Philippines (Gosliner et al. 2008; Gonzales and Gosliner 2014), Japan, and Hawaii (Gosliner et al. 2008). In the WIO it is known from Aldabra (Gosliner et al. 2008) and Mozambique (present study).

Remarks: Our specimen is lighter in colour compared with the more typical reddish colour pattern of $P$. rubrata (see Gosliner et al. 2008: 36).

\section{Conclusions}

Knowledge of marine heterobranchs from Mozambique was limited, with only 16 species mentioned in specialized literature and of those only seven were not collected during our surveys (see Table 2). This low figure reflected not only the extent of the diversity of this faunal group, but a general lack of baseline faunistic and taxonomic research on marine invertebrates in Mozambique. Marine research in Mozambique has been mainly concentrated on fisheries or on the conservation of emblematic organisms like corals, turtles, fish, and mammals (see Bandeira et al. 2002 for a synopsis).

Gosliner et al. (2008) reported the occurrence of 228 shallow-water species of Acteonoidea and Cephalaspidea in the tropical IWP, the most diverse marine biogeographic region of the world (Paulay and Meyer 2002; Williams and Reid 2004; Frey and Vermeij 2008; Gosliner et al. 2008, 2015; Malaquias and Reid 2009); 79 of those species are present in the Indian Ocean and Yonow (2008) listed 47 species inhabiting the Red Sea. In Mozambique alone 39 species are now reported, of which more than half ( 22 species) result from the present contribution; five of those are new records for the Western Indian Ocean.

The diversity of Acteonoidea and Cephalaspidea in Mozambique represents approximately $50 \%$ of the total number of species of these molluscs known in the entire Indian Ocean and $83 \%$ of those known in the Red Sea. Yet, it is certainly an underestimation of the global diversity, as habitats 
such as sandy substrates and mangrove areas have been hardly sampled for these molluscs and will certainly yield new taxa. Previous reports and our sampling efforts were concentrated in the northern and southern areas of the country, whereas the central mangrove/swamp region, almost one-third of the coastline, was not covered (see Fig. 1). Thus, we suggest that future sampling efforts concentrate or at least consider this region.

Acknowledgments We are grateful to all people, colleagues, enterprises, and organizations that have kindly supported our work in Mozambique. This contribution would have never been possible without the help and friendship from lodges and diving centers that have tremendously facilitated our fieldwork, namely the Vamizi Island Lodge and Dive Center / IUCN Conservation project at Vamizi I., Quirimbas (Joana Trindade and Isabel Silva); Nuarro Eco Lodge, Memba (Isabel Fernandes and Yannick Martinet); Kwala Dive Center, Nacala (Mike Donald); Casa Babi \& Odissea Dive Center, Vilanculos (Sabrina Rocco and Denis Dujardin); Barra Lodge \& Dive Center, Barra Beach, Inhambane (Richie O'Connell); Paindane Dive Charter \& Watersport Centre (Vossie Vosloo); Mozdivers (Jon Wright) and Doxa Beach Hotel (Deon Kuhrau), Zavora; and Back to Basics Adventures (Rupert Cornelius and Jenny Stromvoll), Ponta do Ouro. We are grateful to the Peace Parks Foundation and Jenny Stromvoll (Ponta do Ouro Partial Reserve) for organizing collecting permits; to the Natural History Museum of Maputo and in particularly to Dr. Almeida Guissamulo for granting collecting permits, and to Isabel Silva, University Lurio, Pemba for her support in organizing a fieldtrip to Vamizi Island; and finally, to Francisco Mesina (Bazaruto) and Gisela Caldeira (Pemba), who kindly provided images and data of the species Sagaminopteron psychedelicum and Chelidonura livida, respectively. The first author is grateful to the Rufford Foundation for a Small Grant received in 2015.

Open Access This article is distributed under the terms of the Creative Commons Attribution 4.0 International License (http:// creativecommons.org/licenses/by/4.0/), which permits unrestricted use, distribution, and reproduction in any medium, provided you give appropriate credit to the original author(s) and the source, provide a link to the Creative Commons license, and indicate if changes were made.

\section{References}

Adams A (1855) Monographs of Actaeon and Solidula, two genera of gasteropodous mollusca with descriptions of several new species from the Cumingian collection. Proc Zool Soc London 22:58-62

Apte D (2009) Opisthobranch fauna of Lakshadweep Islands, India, with 52 new records to Lakshadweep and 40 new records to India: part 1. J Bombay Nat Hist Soc 106:162

Baba K (1938) Opisthobranchia of Kii, Middle Japan. J Dep Agric Kyusyu Imp Univ 6:1-19

Bandeira SO, Silva RP, Paula J, Macia A, Hernroth L, Guissamulo AT, Gove DZ (2002) Marine biological research in Mozambique: past, present and future. Ambio 31:606-609

Barnard KH (1927) South African Nudibranch Mollusca, with descriptions of new species, and a note on some specimens from Tristan da Cunha. Ann S Afr Mus 25:171-214

Bergh R (1900) Tectibranchia, Lophocercidae, Ascoglossa. In: Semper C (ed) Reisen im archipel der Philippinen. C. W. Kreidel's Verlag, Wiesbaden, pp 159-382

Bergh E (1901) Bullacea. In: Semper C (ed) Reisen im archipel der Philippinen. C. W. Kreidel's Verlag, Wiesbaden, pp 209-256
Bertsch H, Johnson S (1981) Hawaiian nudibranches: a guide for scuba divers, snorkelers, tidepoolers and aquarists. Oriental Publishing Co., Honolulu, Hawaii

Bouchet P (2015a) Aglajidae Pilsbry, 1895 (1847). World Register of Marine Species. http://www.marinespecies.org/aphia.php?p= taxdetails\&id $=22981$

Bouchet P (2015b) Philinopsis cyanea (Martens, 1879). World Register of Marine Species. http://www.marinespecies.org/aphia.php?p= taxdetails\&id $=220968$

Branch GM, Griffiths CL, Branch M, Beckley LE (2008) Two oceans: a guide to the marine life of southern Africa. Struik Nature, Cape Town

Brodie GD, Brodie JE (1990) A checklist of the opisthobranch molluscs of Fiji. J Malacol Soc Aust 11:53-63

Brown GH (1979) An investigation of the anatomy of Colpodaspis pusilla (Mollusca: Opisthobranchia) and a description of a new species of Colpodaspis from Tanzanian coastal waters. J Zool 187:201221

Burn R (2006) A checklist and bibliography of the Opisthobranchia (Mollusca: Gastropoda) of Victoria and the Bass Strait area, southeastern Australia. Mus Vic Sci Rep 10(142):7-13

Burn R, Thompson TE (1998) Order Cephalaspidea. In: Beesley PL, Ross GJB, Wells A (eds) Mollusca: the Southern Synthesis, Fauna of Australia, vol 5. Part B. CSIRO Publishing, Melbourne, pp 943 959

Caballer M, Ortea J, Rivero N, Tucker G, Malaquias MAE, Narciso S (2015) The opisthobranch gastropods (Mollusca: Heterobranchia) from Venezuela: an annotated and illustrated inventory of species. Zootaxa 4034:201-256

Camacho-García YE, Ornelas-Gatdula E, Gosliner TM, Valdés Á (2014) Phylogeny of the family Aglajidae (Pilsbry, 1895) (Heterobranchia: Cephalaspidea) inferred from mtDNA and nDNA. Mol Phylogenet Evol 71:113-126

Carlson C, Hoff PJ (2003) The opisthobranchs of the Mariana Islands. Micronesica 35:271-293

Carmona L, Pola M, Gosliner TM, Cervera JL (2014a) Review of Baeolidia, the largest genus of Aeolidiidae (Mollusca: Nudibranchia), with the description of five new species. Zootaxa 3802:477-514

Carmona L, Lei BR, Pola M, Gosliner TM, Valdés Á, Cervera JL (2014b) Untangling the Spurilla neapolitana (Delle Chiaje, 1841) species complex: a review of the genus Spurilla Bergh, 1864 (Mollusca: Nudibranchia: Aeolidiidae). Zool J Linnean Soc 170:132-154

Domínguez M, Quintas P, Troncoso JS (2007) Phyllidiidae (Opisthobranchia: Nudibranchia) from Papua New Guinea with the description of a new species of Phyllidiella. Am Malacol Bull 22:89-117

Eilertsen MH, Malaquias MAE (2015) Speciation in the dark: diversification and biogeography of the deep-sea gastropod genus Scaphander in the Atlantic Ocean. J Biogeogr 42:843-855

Eliot C (1904) On some nudibranchs from east Africa and Zanzibar. Part VI. Proc Zool Soc London 74:268-298

Eliot C (1905) Nudibranchs from the Indo-Pacific: I., Notes on a collection dredged near Karachi and Maskat. J Conchol II:237-297

Eliot C (1906) Nudibranchs, and tectibranchs from the Indo-Pacific. II., notes on Lophocerus, Lobiger, Haminaea, and Newnesia. J Conchol II:298-315

Frey MA, Vermeij GJ (2008) Molecular phylogenies and historical biogeography of a circumtropical group of gastropods (Genus: Nerita): implications for regional diversity patterns in the marine tropics. Mol Phylogenet Evol 48:1067-1086

García FJG, Domínguez MA, Troncoso JS (2008) Opistobranquios de Brasil. Descripción de opistobranquios del litoral de Brasil y Archipélago Fernando de Noronha. Feito S. L, Spain 
Gofas S, Bouchet P (2015) Philinopsis Pease, 1860. World Register of Marine Species. http://www.marinespecies.org/aphia.php?p= taxdetails\&id $=137640$

Gonzales C, Gosliner TM (2014) Six new species of Philine (Opisthobranchia: Philinidae) from the tropical Indo-Pacific. In: Williams GC, Gosliner TM (eds) The coral triangle: the 2011 Hearst Philippine biodiversity expedition. California Academy of Sciences, San Francisco, pp 353-383

Gosliner TM (1987) Nudibranch of Southern Africa. A guide to opisthobranch molluscs of Southern Africa. Sea Challengers, Jeff Hamann $\&$ California Academy of Science, California

Gosliner TM (2011) Six new species of Aglajid opisthobranch mollusks from the tropical Indo-Pacific. Zootaxa 2751:1-24

Gosliner TM, Behrens DW, Valdés Á (2008) Indo-Pacific nudibranchs and sea slugs: a field guide to the world's most diverse fauna. Sea Challengers Natural History Books, California

Gosliner TM, Valdés Á, Behrens DW (2015) Nudibranchs \& sea slugs. Identification. Indo-Pacific. New World Publications, Inc., Jacksonville

Heller J, Thompson TE (1983) Opisthobranch molluscs of the Sudanese Red Sea. Zool J Linnean Soc 78:317-348

Héros V, Lozouet P, Maestrati P, von Cosel R, Brabant D, Bouchet P (2007) Mollusca of New Caledonia Compendium of marine species of New Caledonia, Doc Sci Tech 2nd edn Institut de recherche pour le développement, Nouméa, New Caledonia. II7:199-254

Hoover JP (1998) Hawai'i's sea creatures. A guide to Hawai'i's marine invertebrates. Mutual Publishing, Honolulu

Jörger KM, Stöger I, Kano Y, Fukuda H, Knebelsberger T, Schrödl M (2010) On the origin of Acochlidia and other enigmatic euthyneuran gastropods, with implications for the systematics of Heterobranchia. BMC Evol Biol 10:323

Johnson S, Boucher LM (1983) Notes on some Opisthobranchia (Mollusca: Gastropoda) from the Marshall Islands, including 57 new records. Pac Sci 37(3):251-291

Kay EA (1979) Hawaiian marine shells: reef and shore fauna of Hawaii section 4. Mollusca. Bishop Museum Press, Honolulu

Kay EA, Wells FN, Ponder WF (1998) Gastropoda. In: Beesley PL, Ross GJB, Wells A (eds) Mollusca: the Southern Synthesis, Fauna of Australia, vol 5. Part A. CSIRO Publishing, Melbourne, pp 565-604

Kilburn RN, Rippey E (1982) Sea shells of Southern Africa. Macmillan South Africa, Johannesburg

King D, Fraser V (2014) The reef guide: fishes, corals, nudibranchs \& other invertebrates East \& South Coasts of Southern Africa. Random House Struik Nature, Cape Town

Macnae W, Kalk M (1958) A natural history of Inhaca Island, Mozambique. Witwatersrand Univ. Press, Johannesburg

Macnae W, Kalk M (1962) The fauna and flora of sand flats at Inhaca Island, Moçambique. J Anim Ecol 31:93-128

Malaquias MAE, Reid DG (2008) Systematic revision of the recent species of Bullidae (Mollusca: Gastropoda: Cephalaspidea), with a molecular phylogenetic analysis. Zool J Linnean Soc 153:453-543

Malaquias MAE, Reid DG (2009) Tethyan vicariance, reliction and speciation: evidence from a global molecular phylogeny of the opisthobranch genus Bulla. J Biogeogr 36:1760-1777

Malaquias MAE, Dodds JM, Bouchet P, Reid DG (2009) A molecular phylogeny of the Cephalaspidea sensu lato (Gastropoda: Euthyneura): Architectibranchia redefined and Runcinacea reinstated. Zool Scr 38:23-41

Malaquias MAE, Zamora-Silva A, Vitale D, Spinelli A, De Matteo S, Giacobbe S, Ortigosa D, Cervera JL (2016) The Mediterranean Sea as a gateway for invasion of the Red Sea: the case of the Indo-West Pacific head-shield slug Chelidonura fulvipunctata Baba, 1938. Aquat Invasions (in press)

Marcus EDBR, Marcus E (1970) Some gastropods from Madagascar and West Pacific. Malacologia 10:181-223
Marshall JG, Willan RC (1999) Nudibranchs of Hereon Island, Great Barrier Reef. A survey of the Opisthobranchia (sea slugs) of Heron and Wistari reefs. Backhuys Publishers, Leiden

Mikkelsen PM (1996) The evolutionary relationships of Cephalaspidea s.l. (Gastropoda: Opisthobranchia): a phylogenetic analysis. Malacologia 37:375-442

Ministry for the Coordination of Environmental Affairs (1997) First national report on the conservation of biological diversity in Mozambique. IMPACTO Ltda, Maputo

Moretzsohn F, Kay EA (1995) Hawaiian marine molluscs - an update to Kay, 1979 (unpublished manuscript distributed at the 61st American Malacological Union Congress, held at the University of Hawaii at Hilo, Hawaii). University of Hawaii at Manoa, Honolulu, Hawaii, pp 24

Moro L, Ortea J, Bacallado JJ, Caballer M, Acevedo I (2003) Anaspidea, Cephalaspidea, Gymnosomata, Notaspidea, Nudibranchia, Sacoglossa y Thecosomata. In: Moro L, Martín JL, Garrido MJ, Izquierdo I (eds) Lista de especies marinas de Canarias (algas, hongos, plantas y animales). Banco de Datos de Biodiversidad de Canarias. Consejería de Política Territorial y Medio Ambiente del Gobierno de Canarias, pp 248

Nakano R (2004) Opisthobranchs of Japan Islands. Rutles Inc, Tokyo

Narayana S, Mohanraju R (2013) New record of a headshield slug Phanerophthalmus smaragdinus (Gastropoda: Opisthobranchia) from Andaman Islands, India. J Threatened Taxa 5:4113-4114

Nordsieck F (1972) Die europäischen Meeresschnecken (Opisthobranchia mit Pyramidellidae; Rissoacea) vom Eismeer bis Kap-verden, Mittelmeer uns Schwarzes Meer. Gustav Fischer Verlag, Stuttgart, 327p

Obura D (2012) The diversity and biogeography of western Indian ocean reef-building corals. PLoS ONE 7:e45013. doi:10.1371/journal. pone. 0045013

Ornelas-Gatdula E, Valdés A (2012) Two cryptic and sympatric species of Philinopsis (Cephalaspidea: Aglajidae) in the Bahamas distinguished using molecular and anatomical data. J Molluscan Stud 78(4):313-320

Oskars TR, Bouchet P, Malaquias MAE (2015) A new phylogeny of the Cephalaspidea (Gastropoda: Heterobranchia) based on expanded taxon sampling and gene markers. Mol Phylogenet Evol 89:130 150

Padula V, Bahia J, Correia MD, Sovierzoski HH (2012) New records of opisthobranchs (Mollusca: Gastropoda) from Alagoas, northeastern Brazil. Mar Biodivers Rec 5:e57

Padula V, Wirtz P, Schrödl M (2014) Heterobranch sea slugs (Mollusca: Gastropoda) from Ascension Island, South Atlantic Ocean. J Mar Biol Assoc UK : $1-10$

Paulay G, Meyer C (2002) Diversification in the tropical Pacific: comparisons between marine and terrestrial systems and the importance of founder speciation. Integr Comp Biol 42:922-934

Pereira MAM et al (2014) Mozambique marine ecosystems review. Final report submitted to fondation ensemble. Biodinâmica \& CTV, Maputo

Pilsbry H (1921) Marine mollusks of Hawaii I-XV. Proc Acad Nat Sci Phila 72:296-328

Price RM, Gosliner TM, Valdes A (2011) Systematics and phylogeny of Philine (Gastropoda: Opisthobranchia), with emphasis on the Philine aperta species complex. Veliger 51:1-58

Quirk SJ, Wolfe CS (1974) Seashells of Hawaii. WW Distributors

Robin A (2008) Encyclopedia of Marine Gastropods. ConchBooks; Hackenheim. 480p

Rolán E (2005) Malacological fauna from Cape Verde archipelago, part 1, Polyplacophora and Gastropoda. Conchbooks, Hackenheim

Rudman WB (1970) Chelidonum inomata Baba and C. electra sp. nov. from the Solomon Islands (Opisthobranchia; Aglajidae). J Mal Soc Aust 2:7-12 
Rudman WB (1971) The family Acteonidae (Opisthobranchia, Gastropoda) in New Zealand. J Mal Soc Aust 2:205-214

Rudman WB (1972a) A comparative study of the genus Philinopsis Pease, 1860 (Aglajidae, Opisthobranchia). Pac Sci 26:381-399

Rudman WB (1972b) The genus Philine (Opisthobranchia, Gastropoda). Proc Malacol Soc Lond 40:171-187

Rudman WB (1973) On some species of Chelidonura (Opisthobranchia: Aglajidae) from Zanzibar and Fiji. Zool J Linnean Soc 52:201-215

Rudman WB (1974) A comparison of Chelidonura, Navanax and Aglaja with other genera of the Aglajidae (Opisthobranchia: Gastropoda). Zool J Linnean Soc 54:185-212

Schrödl M (2014) Time to say "bye-bye pulmonata"? Spixiana 37:161-164

Sreeraj CR, Sivaperuman C, Raghunathan C (2012) An annoted checklist of opisthobranch fauna (Gastropoda: Opisthobranchia) of the Nicobar Islands, India. JoTT 4:2499-2509

Sreeraj CR, Sivaperuman C, Raghunathan C (2013) Species diversity and abundance of opisthobranch molluscs (Gastropoda: Opisthobranchia) in the coral reef environments of Andaman and Nicobar Islands, India. In: Ecology and conservation of tropical marine faunal communities. Springer, pp 81-106

Ternon JF, Bach P, Barlow R, Huggett J, Jaquemet S, Marsac F, Ménard F, Penven P, Potier M, Roberts MJ (2014) The Mozambique Channel: from physics to upper trophic levels. Deep Sea Res (II Top Stud Oceanogr) 100:1-9

Turner LM, Wilson NG (2012) The Chelidonura tsurugensis-sandrana (Gastropoda: Cephalaspidea) species complex: do reproductive decisions maintain colour polymorphism? J Molluscan Stud 78:166-172

Valdés A, Hamann J, Behrens DB, DuPont A (2006) Caribbean sea slugs: a field guide to the opisthobranch mollusks from the tropical northwestern Atlantic. Sea Challengers Natural History Books, Washington, DC

von Martens E (1879) Übersicht der von Peters 1843-1847 in Mosambique gesammelten Molluska vol 1879. Monatsberichte der Königlichen Preussischen Akademie der Wissenschaften zu Berlin, Berlin
Vonnemann V, Schrödl M, Klussmann-Kolb A, Wägele H (2005) Reconstruction on the phylogeny of the Opisthobranchia (Mollusca: Gastropoda) by means of $18 \mathrm{~S}$ and $28 \mathrm{~S}$ rRNA gene sequences. J Molluscan Stud 71:113-125

Voskuil MI, Voepel K, Chambliss GH (1995) The-16 region, a vital sequence for the utilization of a promoter in Bacillus subtilis and Escherichia coli. Mol Microbiol 17:271-279

Wagele H, Burghardt I, Anthes N, Evertsen J, Klussmann-Kolb A, Brodie GD (2006) Species diversity of opisthobranch molluscs on Lizard Island, Great Barrier Reef, Australia. Rec Aust Mus 69:33-59

Williams ST, Reid DG (2004) Speciation and diversity on tropical rocky shores: a global phylogeny of snails of the genus Echinolittorina. Evolution 58:2227-2251

Wirtz P (1999) Hydatina physis (Mollusca: Gastropoda: Opisthobranchia) from the Azores. Arquipélago, Life Mar Sci 17A:97-99

World Register of Marine Species (2015) http://www.marinespecies.org at VLIZ. Accessed 2015-10-02

Yonow N (1993) Opisthobranchs from the Maldive Islands, including descriptions of seven new species (Mollusca: Gastropoda). Rev Fr d'Aquariologie 20(4):97-129

Yonow N (1994) A new species and a new record of Chelidonura from the Red Sea (Cephalaspidea: Aglajidae). J Conchol 35:141-147

Yonow N (2000) Red Sea Opisthobranchia 4: the orders Cephalaspidea, Anaspidea, Notaspidea and Nudibranchia: Dendronotacea and Aeolidacea. Fauna Arabica 18:87-131

Yonow N (2008) Sea slugs of the Red Sea, vol 74. Pensoft Pub

Yonow N (2012) Opisthobranchs from the Western Indian Ocean, with descriptions of two new species and ten new records (Mollusca, Gastropoda). Zookeys 197:1-129

Yonow N, Hayward PJ (1991) Opisthobranches de l'lle Maurice, avec la description de deux espèces nouvelles (Mollusca: Opisthobranchia). Rev Fr Aquariologie Herpétologie 18:1-30

Yonow N, Anderson RC, Buttress SG (2002) Opisthobranch molluscs from the Chagos Archipelago, Central Indian Ocean. J Nat Hist 7: $831-882$ 